Acta Universitatis Nicolai Copernici • Pedagogika XL/2/2020

Nauki Humanistyczno-Społeczne • Zeszyt 452

DOI: http://dx.doi.org/10.12775/AUNC_PED.2020.011

\title{
Amelia Krawczyk-Bocian
}

https://orcid.org/0000-0002-3519-2212

\section{Roman Leppert}

https://orcid.org/0000-0002-4809-5163

Wydział Pedagogiki

Uniwersytet Kazimierza Wielkiego w Bydgoszczy

\section{NARRACJA JAKO TEMPORALNA PODRÓŻ PO ŚWIECIE SENSÓW I ZNACZEŃ}

\author{
Narration as a Temporal Journey \\ Around the World of Senses and Meanings
}

\begin{abstract}
Abstrakt
Przedmiotem artykułu jest narracja, towarzysząca człowiekowi w toku biograficznego życia. Tak pojmowana narracja występuje w zwyczajnej ludzkiej rozmowie, która pozwala zarówno narratorowi, jak i słuchającym narracji podążać temporalną drogą indywidualnej historii życia. W opracowaniu zostały wyróżnione i omówione rozumienia narracji jako: „znamię momentu historycznego" (za Normanem Denzinem), opowieść w drodze, narracja świadka. Całość kończy charakterystyka potocznego pojmowania narracji jako opowieści w drodze.

Słowa kluczowe: narracja, narracja świadka, biografia, potoczność, narracja jako opowieść
\end{abstract}




\begin{abstract}
The subject of the article is the narrative accompanying man in the course of his biographical life. Narrative understood in this way occurs in ordinary human conversation, which allows both the narrator and the narrator to follow the temporal path of the individual history of life. The study distinguishes and discusses the understandings of the narrative as "a mark of a historical moment" (after Norman Denzin), a story on the way, a witness's narrative. The whole thing ends with a description of the common understanding of narration as a story on the go.
\end{abstract}

Ke y w ords: narrative, witness narrative, biography, commonness, narrative as a story

\title{
Wprowadzenie
}

Drzedmiotem niniejszych rozważań czynimy narrację towarzyszącą - człowiekowi w toku biograficznego życia. Pragniemy wykazać, że tworzenie opowieści narracyjnej zaprasza człowieka do układania historii życia w odcinki czasu. W takim ujęciu możemy mówić za Teunem A. van Dijkiem ${ }^{1}$ o narracji naturalnej występującej w potocznej, zwyczajnej ludzkiej rozmowie. Codziennej opowieści, która zaprasza zarówno narratora, jak i „rodzimych” słuchaczy do podążania temporalną drogą indywidualnej historii życia.

Wprowadzona kategoria pojęciowa narracji ujęta zostaje z perspektywy możliwości wsłuchania się w głos podmiotów społecznego dyskursu, uczestników kultury, refleksyjnych badaczy. Wszystkich tych, którzy świadomie biorą udział w kreowaniu, tworzeniu, rozczytaniu przestrzeni życia współczesnego człowieka. Opowieść narracyjna prowadzi tym samym do (z)rozumienia istoty podejmowanych działań, zadań, wyzwań wpisanych w ludzką wędrówkę po zakamarkach przestrzeni ich najbliższego, społecznego świata.

${ }^{1}$ T.A. van Dijk, Działanie, opis działania a narracja, „Pamiętnik Literacki. Czasopismo Kwartalne Poświęcone Historii i Krytyce Literatury Polskiej”, 1985 t. 76 nr 11, s. 146. 
Podjętym rozważaniom przewodzić będzie myśl Anny Gałdowej², dla której „przeżywanie chwili, jej przemijanie, przeszłość i przyszłość mają dla człowieka znaczenie i są przez niego ujmowane przede wszystkim ze względu na treść zdarzeń, ich sens, oraz - co szczególnie ważne - ze względu na poczucie własnej tożsamości". W tym kontekście będzie mowa o narracji, którą nazywamy narracją w drodze. To temporalna podróż współczesnego człowieka po ważnych, znaczących dla niego obszarach życia. Narracja w drodze będzie zatem przybierać formę komunikatu, który narratorzy wysyłają innym ludziom żyjącym wokół, chcącym wraz z nimi przyjrzeć się historii życia. Komunikowanie innym zdarzeń z biografii indywidualnej stawia tym samym narratora przed koniecznością wyboru tych z nich, które są dla niego ważne, znaczące czy wyjątkowe. W takiej sytuacji narrator nie podejmuje się zadania opisania, wyjaśnienia czy interpretowania wszystkich zdarzeń i epizodów z życia szczegółowo. Narrator dokonuje ich selekcji, wybiera te, które wyznaczyły bieg jego dalszego życia, pozwoliły określić system wartości czy znaczeń, stały się dla niego punktem zwrotnym (przełomowym) ${ }^{3}$. Z drugiej strony dokonanie selekcji zdarzeń, ich wybór przez narratora, może być również związane z trudnościami przywoływania z pamięci absolutnie wszystkich zdarzeń, zwłaszcza tych odległych. W takiej sytuacji koncentracja na tych szczególnie ważnych (z punktu widzenia narratora) wydaje się uzasadniona. Pamięć jest ulotna, a przywoływanie wszystkich zdarzeń - po prostu niemożliwe. Stąd też narrator decyduje o tym, co z jego punktu widzenia jest istotne, znaczące, co chce przekazać innym.

Mówiąc o ludzkiej zdolności przywoływania z pamięci zdarzeń ujętych z perspektywy czasu, przyjmujemy propozycję Olgi Czerniawskiej ${ }^{4}$. Autorka proponuje podejść do pamięci jako pewnej sfery przy-

2 A. Gałdowa, Powszechność i wyjątek. Rozwój osobowości człowieka dorosłego, Kraków 1995, s. 128.

3 Por. E. Mazurek, Narracyjne uczenie się człowieka dorosłego. Założenia teoretyczne, „Nauki o Wychowaniu. Studia Interdyscyplinarne”, 2017 nr 1(4). DOI: https://doi.org/10.18778/2450-4491.04.07.

4 O. Czerniawska, Podróż w pamięci starszych, „Edukacja Dorosłych”, 2003 nr 1. 
pominania, wspominania, przeżywania ponownie pewnych obrazów, sytuacji, spotkań z innymi. Będzie to zatem powrót do lat dzieciństwa, młodości spędzonych w rodzinie, wśród osób znaczących, biograficznie ważnych, oddziałujących na dalszy bieg życia narratora.

Narracja w drodze jako temporalny wyraz budowania znaczeń osobistych zaprasza tym samym zarówno narratora, jak i słuchaczy, obserwatorów współczesnego świata, do podróży po zakamarkach ludzkiego życia. Zachęca do powrotu do zdarzeń nie tylko miłych, przyjemnych, radosnych, ale przede wszystkim tych, które wymagają ponownego spotkania z samym sobą i najbliższymi Innymi. Spotkanie po latach z biograficznymi zdarzeniami, determinującymi sytuacjami stawia narratora przed koniecznością akceptacji swego dotychczasowego życia, ludzi, momentów przełomowych, granicznych. Aby móc podołać temu jakże trudnemu zadaniu, Paul Ricoeur ${ }^{5}$ proponuje wprowadzić i zaakceptować w życiu współczesnego człowieka kategorię pojęciową przebaczenia. Zdaniem autora przebaczenie ,jest swego rodzaju uzdrowieniem pamięci, położeniem kresu żałobie. Pamięć uwolniona od ciężaru długu dysponuje swobodą angażowania się $\mathrm{w}$ wielkie projekty. Przebacze-

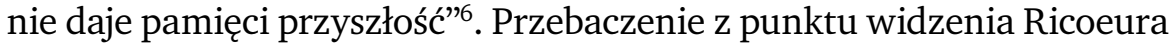
staje się przepustką do nowego wymiaru życia, do antycypowanej przyszłości wolnej od ciężaru trudów przeszłości.

Rozbudzenie woli snucia opowieści narracyjnej daje początek udziałowi w twórczym tworzeniu obrazu siebie w perspektywie czasu. Zgoda na uzewnętrznienie treści przeżyć i doświadczeń pozwala przywoływać z pamięci wyjątkowe osoby, przyglądać się im z dystansu, z nutą krytycyzmu. Przywoływanie zdarzeń, ich porządkowanie na linii czasu, może przynieść tym samym ulgę, wyciszenie, wewnętrzne zintegrowanie. Może sprzyjać refleksyjności i jej zdolności do tzw. decentracji rozumianej jak spoglądanie na obiekty i sytuacje innych osób z różnych perspektyw ${ }^{7}$. Refleksyjność towarzyszyć będzie człowiekowi

5 P. Ricoeur, Pamięć, historia, zapominanie, Kraków 1995.

6 Tamże, s. 41.

7 M. Chądzyńska, Modalność w tekście a ustosunkowanie do świata. Wybrane aspekty metody badania autonarracji, w: Narracja. Teoria i praktyka, red. B. Janusz, K. Gdowska, B. Barbaro, Kraków 2008, s. 173. 
tworzącemu świadomie i z zaangażowaniem swoją indywidualną narrację w drodze.

Podążanie narracyjną drogą staje się okazją do przyglądania się nie tylko własnemu życiu. To również obserwowanie historii życia innych ludzi, podejmowanych przez nich decyzji, ich poczynań, celów, do których dążyli (dążą). W takim ujęciu narracja w drodze to nie tylko cofanie się do zdarzeń z przeszłości. To stawianie pytań o antycypowaną przyszłość, o możliwość zaspokojenia potrzeb i pragnień w niedalekim czasie. Narrator staje się zatem człowiekiem pytającym, doświadczającym wewnętrznej, biograficznej przemiany ${ }^{8}$. Udział w tworzeniu narracji $\mathrm{w}$ drodze stwarza szansę ponownego spotkania $\mathrm{z}$ samym sobą w gąszczu pytań, nieujawnionych spraw, nierozstrzygniętych sporów. Narracja w drodze rozbudza pokłady refleksyjności, „zdolności generowania wiedzy o sobie i otaczającym świecie"”.

\section{Narracja jako „znamię momentu historycznego”"}

Zaznaczając ważność nauk humanistycznych na mapie paradygmatów, Wilhelm Dilthey ${ }^{10}$ podkreślił fakt, że świat ludzki zdecydowanie różni się od świata przyrody. Pojawienie się opozycji związanej z przedmiotem badań nauk przyrodniczych i przedmiotem nauk humanistycznych rozpoczęło uzasadnioną dyskusję nad powstaniem antynaturalistycznej filozofii humanistyki ${ }^{11}$. W związku z powyższym badania nie mogły już odwoływać się tylko i wyłącznie do rejestracji faktów. Musia-

Termin pochodzi od Normana K. Denzina z artykułu: Reinterpretacja metody biograficznej $w$ socjologii: znaczenie a metoda $w$ analizie biograficznej, w: Metoda biograficzna w socjologii, red. J. Włodarek, M. Ziółkowski, Warszawa-Poznań 1990, s. 55-69.

8 M. Adamiec, Doświadczenie przemiany jako kategoria psychologiczna, Katowice 1988, s. 143.

9 D. Lalak, Życie jako biografia. Podejście biograficzne $w$ perspektywie pedagogicznej, Warszawa 2010, s. 392.

10 W. Dilthey, Rozumienie i życie, w: Wokół rozumienia. Studia i szkice z hermeneutyki, red. G. Sowiński, Kraków 1993.

11 T. Hejnicka-Bezwińska, Praktyka edukacyjna $w$ warunkach zmiany kulturowej (w poszukiwaniu logiki zmian), Warszawa 2015. 
ły zostać skierowane na to, co ukryte, niepowtarzalne, niewyjaśnione. Odwoływanie się do naczelnej doktryny XIX wieku - pozytywizmu, przyjmującego intelektualizm, optymizm poznawczy, procedury naukowe dążące do uzyskania pewnej i obiektywnej wiedzy o człowie$\mathrm{ku}$, przestało wystarczać ${ }^{12}$. Badacze - uczeni skierowali swoją uwagę na poznanie świata człowieka, zdarzeń z jego indywidualnej historii życia, przestrzeni, w której przeżywa codzienną egzystencję i jej doświadcza. Możliwość odczytania, wyjaśnienia i poddania interpretacji życia człowieka, jego zaangażowania w proces zrozumienia i rozczytania historii życia stała się sprawą nadrzędną.

Pojawienie się paradygmatu humanistyczno-interpretatywnego otworzyło drogę do przyglądania się (wraz z innymi) wewnętrznemu życiu jednostki. Zapoczątkowało to badania ukierunkowane na potrzebę odczytania podmiotowości człowieka i jego uczestnictwa w kulturze $^{13}$. Lata 70. i 80. XX wieku przyniosły odpowiedź na ludzką potrzebę czynienia świata zrozumiałym, czytelnym dla wszystkich biorących aktywny udział w tworzeniu rzeczywistości społecznej. Autonomizacja nauk humanistycznych doprowadziła do rozkwitu różnorodnych metod badań jakościowych, z możliwością wykorzystania i gromadzenia materiałów empirycznych, tj. studiów przypadku, biografii, wywiadów, wywiadów narracyjnych, wytworów kultury, tekstów kultury i innych ${ }^{14}$.

Zastosowanie w procesie badawczym bogactwa metod umożliwiało lepsze odczytanie świata współczesnego człowieka, zrozumienie jego relacji z samym sobą, jak i innymi ludźmi w przestrzeni wspólnego życia. Stąd też przedmiotem namysłu humanistycznego uczyniono przede wszystkim zachowanie się człowieka w jego społecznym świecie. Skierowano uwagę nie tylko na to, w jaki sposób człowiek zachowuje się w codziennej rzeczywistości, ale przede wszystkim na to, w jaki sposób

12 W. Kruszelnicki, Zwrot refleksyjny $w$ antropologii kulturowej, Wrocław 2012.

13 Zob. M. Cuprjak, Paradygmaty $w$ perspektywie zmian społecznych. Zarys problemu, „Rocznik Andragogiczny”, 2016 t. 23. DOI: http://dx.doi.org/10.12775/ RA.2016.013.

14 D.K. Norman, Wprowadzenie. Dziedzina i praktyka badań jakościowych, w: Metody badań jakościowych, t. 1, red. N.K. Denzin, Y.S. Lincoln, Warszawa 2009. 
jego zachowanie oddziałuje na relacje $\mathrm{z}$ innymi, na znaczenie danego zachowania z perspektywy minionego czasu' ${ }^{15}$. Badanie życia człowieka zostało wzbogacone o czynnik emocjonalny. Uzewnętrznianie pokładów emocji, wyrażanie uczuć, komunikowanie stanu, w którym obecnie człowiek się znajduje, dały wyraz konieczności badania tych form egzystencji człowieka, które definiują jego istnienie ujęte właśnie z perspektywy czasu. W toku rozwoju badań humanistycznych zaczęto odkrywać świat ludzkich doznań, przeżyć, oczekiwań. Zaczęto wsłuchiwać się w głos człowieka ujawniającego swoje pragnienia, marzenia, wolę tworzenia przyjaznego mu świata społecznego, w którym może działać i tworzyć.

Badacze jakościowi skierowali zatem szczególną uwagę na podejmowane przez człowieka działania związane z tworzeniem wokół siebie przestrzeni, umożliwiającej im zaspokajanie potrzeb związanych $\mathrm{z}$ ich uczestnictwem w kulturze. W takim ujęciu internalizacja stała się warunkiem rozumienia siebie i innych ludzi, warunkiem postrzegania świata jako rzeczywistości znaczącej z perspektywy doświadczającego podmiotu ${ }^{16}$. Człowiek stał się zdolny do (z)rozumienia otaczającego świata, dostrzegania jego roli, podejmowanych wyzwań w procesie kształtowania tożsamości osobowej i społecznej. Ów świat stał się dla niego indywidualnym światem, któremu mógł nadać sens i znaczenie.

Próba odczytania świata człowieka w całej jego nieprzejrzystości, wielowątkowości czy złożoności skierowała badaczy ku narratywistycznej wizji badań. Konsekwencją poszukiwań odpowiedzi na nurtujące badaczy pytania dotyczące jednostkowego wyrażania przeżyć i doświadczeń człowieka był rozkwit narratywistycznej myśli humanistycznej w latach 80. i 90. XX wieku. Zainteresowanie badaczy odkryciem subiektywnego świata życia współczesnego człowieka doprowadziło do rozwoju metody narracyjnej jako szczególnie owocnej dla pozyskiwania danych empirycznych. Zainteresowanie badaczy narracjami wynikło również z przekonania o wszechobecności narracji w kulturze współ-

15 Zob. W. Kruszelnicki, Zwrot refleksyjny $w$ antropologii kulturowej, dz. cyt.

16 P.L. Berger, T. Luckmann, Społeczne tworzenie rzeczywistości. Traktat z socjologii wiedzy, Warszawa 1983. 
czesnego świata ${ }^{17}$. Metoda narracyjna nieustannie zwiększała grono swoich zwolenników ${ }^{18}$.

Celem badań narracyjnych uczyniono zrozumienie życia człowieka, rzeczywistości, w której codziennie podejmuje się nowych wyzwań i zadań. Wydobywanie sensów i znaczeń z osobistych przeżyć i doświadczeń człowieka znajdowało swoje odzwierciedlenie w badaniach na gruncie literatury, antropologii filozoficznej, psychologii, pedagogiki, historii ${ }^{19}$. Jak zauważa Katarzyna Rosner ${ }^{20}$ : „pojęcie narracji weszło dziś do słownika pojęć zarówno filozofii, jak i nauk społecznych, zwłaszcza w rozważaniach, które poszukują tożsamości jednostki i specyfiki współczesnej kultury, określanej często jako kultura ponowoczesna - a więc psychologii, socjologii, a także historii”. Każda z dyscyplin starała się dotrzeć do subiektywnego świata człowieka, doświadczeń kształtujących jego rozwój w biegu życia. Próbowała odnieść się do opinii, przekonań narratora jako uczestnika świata życia człowieka, w którym działa on jako wolny, świadomy podmiot. Stąd też, jak zauważa Anna Burzyńska ${ }^{21}$ : „zwrot narratywistyczny oznaczał przemieszczenie refleksji nad narracją i poszerzenie zakresu znaczeniowego narracji - od narracji literackiej, poprzez narrację jako przedmiot dociekań teorii literatury (poetyki) i semiotyki literackiej, do narracji będącej kategorią innych dyscyplin humanistycznych. I jako taki zwrot ten został uznany za najbardziej znaczącą przemianę myśli XX wieku - zaraz po zwrocie lingwistycznym". Wejście narracji na scenę badań humanistycznych i społecznych uruchomiło płaszczyznę dyskursu pomiędzy człowiekiem a światem, w którym człowiek na co dzień funkcjonuje. Narracje stały się zamierzonym działaniem komunikacyjnym, uruchamianym z pewną intencją, zamiarem czy koniecz-

17 T. Hejnicka-Bezwińska, Praktyka edukacyjna, dz. cyt.

${ }^{18}$ S. Chase, Wywiad narracyjny. Wielość perspektyw, podejść, głosów, w: Metody badań jakościowych, t. 2, red. N.K. Denzin, Y.S. Lincoln, Warszawa 2009.

19 A. Krawczyk-Bocian, Narracja w pedagogice. Teoria. Metodologia. Praktyka badawcza, Bydgoszcz 2019.

${ }^{20}$ K. Rosner, Narracja jako struktura rozumienia, „Teksty Drugie”, $1999 \mathrm{nr}$ 3, s. 7.

${ }^{21}$ A. Burzyńska, Idee narracyjności w humanistyce, w: Narracja. Teoria i praktyka, red. B. Janusz, K. Gdowska, B. Barbaro, Kraków 2008, s. 27-28. 
nością przez opowiadającego (autora). W takim ujęciu narrator stał się przewodnikiem po świecie swoich indywidualnych przeżyć i doświadczeń. Osobą najbardziej zorientowaną w tym, co jej się przydarzyło.

Odwoływanie się do narracji uczyniło z niej jedno z najdoskonalszych mediów znaczeń ${ }^{22}$. W związku z powyższym zaczęto odwoływać się do narracji jako „tekstu jednostkowego”, „tekstu osoby” czy „tekstu kultury"23. W pierwszym ujęciu mówi się o narracji jako pewnej realizacji językowej, dzięki której można opowiadać innym okoliczności zdarzeń i sytuacji z przestrzeni indywidualnego życia. W takim ujęciu narracja może występować w formie pisemnej bądź ustnej. Swym zasięgiem obejmuje zarówno „wielkie”, jak i „małe” narracje ${ }^{24}$. „Wielkie narracje” opowiadają o wielkich, ważnych wydarzeniach, o wielkich, istotnych problemach i o wielkich, silnych przeżyciach, te zaś, w zindywidualizowanej postaci, uobecniają się w biografii pojedynczego człowieka, a następnie znajdują wyraz w jego osobistej opowieści życia, czyli w „małej narracji”. Zarówno te „małe”, jak i „duże” narracje uruchamiają w jednostce potrzebę i chęć dzielenia się z innymi swoimi myślami, spostrzeżeniami, smutkami. Są wyrazem troski o uczynienie najbliższego świata czytelnym, przejrzystym, ciągłym. Narracje stały się „przepustką” do odkrycia codziennego świata, w którym jednostka funkcjonuje, wchodzi w relacje interpersonalne $\mathrm{z}$ innymi ludźmi w przestrzeni jej biograficznego życia.

W drugim ujęciu, rozumianym jak tekst osoby, narracja jest postrzegana jako system znaczeń ${ }^{25}$. W tym ujęciu znaczenia, jakie nadaje człowiek przeżytym zdarzeniom $\mathrm{w}$ biografii indywidualnej, są wpisane w tzw. schemat narracyjny. Wywodzi się on z „doświadczeń o charakterze werbalnym" - z opowiadania. Dlatego jako jedyny może dotyczyć interpretacji i oceny zdarzeń z „najwyższego piętra” znaczeń (warstwy podmiotowo-egzystencjalnej) ${ }^{26}$. W schemacie narracyjnym na plan

22 E. Dryll, Homo narrans - wprowadzenie, w: Narracja. Koncepcje i badania psychologiczne, red. E. Dryll, A. Cierpka, Warszawa 2004.

23 Tamże, s. 9-12.

24 M. Straś-Romanowska, Psychologia wobec matych $i$ wielkich narracji, w: Psychologia małych $i$ wielkich narracji, red. M. Straś-Romanowska, B. Bartosz, M. Żurko, Warszawa 2010, s. 26.

25 E. Dryll, Homo narrans - wprowadzenie, dz. cyt., s. 10.

26 Tamże. 
pierwszy wysuwa się narrator - główny bohater opowieści. To on z perspektywy minionego czasu relacjonuje trudne determinujące zdarzenia, ukazuje ich przebieg, wskazuje na uruchomione strategie radzenia sobie z problemami, określa drogę realizacji planów, wyzwań, oczekiwań ${ }^{27}$. Narracja ujęta jako „tekst osoby” zaprasza zatem do śledzenia (za autorem opowieści narracyjnej) życia, jego poszczególnych etapów, momentów przełomowych, krytycznych czy wzniosłych. Tekst osoby niesie niewątpliwie wartość poznawczą. Służy poznaniu i rozumieniu życia innych, jak i każdego z nas. Tym samym, ucząc się z biografii innych, mamy możliwość zdobywania wiedzy o nas samych. Wynika z tego, że z tekstu inni ludzie dowiadują się, że żyją obok nich osoby o podobnych problemach, troskach, doświadczeniach. Dostrzegając ich obecność w swoim życiu, nie czują się osamotnieni w przestrzeni swego ziemskiego życia. Następuje proces identyfikacji ze „znaczącymi innymi” bądź „biograficznymi idolami”.

Trzecie podejście ujmuje narrację jako „tekst kultury”. Przekazywany „tekst” obejmuje wartości, symbole, znaczenia, które są przekazywane człowiekowi z pokolenia na pokolenie. $\mathrm{W}$ toku swojego życia człowiek poznaje je, włącza do systemu znaczeń, czyni go ważnym i znaczącym w obrębie kultury, w której przebywa. W procesie socjalizacji pierwotnej zarówno rodzice, jak i najbliższa rodzina wprowadzają dziecko w świat norm, zasad, którymi sami w życiu codziennym się kierują. Przywoływane mity, legendy, wierzenia czy opowieści z dawnych lat pozwalają odczytać zawarte $\mathrm{w}$ nich treści kultury, przyswajać te, które w kontekście aktualnego życia wydają się ważne i biograficznie znaczące. Poznawanie i rozczytanie tekstów kultury oddziałuje pozytywnie na rozwój człowieka, w tym na jego kompetencje narracyjne ujawniające się w możliwości tworzenia indywidualnych narracji, nazwanych powyżej tekstami osoby ${ }^{28}$. W procesie edukacji od najwcześniejszych już lat młodzi ludzie są zapraszani do rozczytania tekstów kultury. W taki sposób edukacja zorientowana instytucjonalnie wyposaża ich w system warto-

27 Zob. J. Trzebiński, Narracyjne konstruowanie rzeczywistości, w: Narracja jako sposób rozumienia świata, red. J. Trzebiński, Gdańsk 2002, s. 23.

28 Por. E. Mazurek, Narracyjne uczenie się człowieka dorosłego. Założenia teoretyczne, dz. cyt. 
ści, znaczeń. W procesie edukacji podejmowane są rozważania nie tylko o czasie minionym, ale również tym, który jest dla nich namacalny, najbardziej znany i rozpoznany. Wprowadzanie młodych ludzi w obszar kultury pozwala im rozumieć problematyczność współczesnego świata, rozstrzygać sporne kwestie, doświadczać siebie z perspektywy aktywnych członków kultury. Jednostka staje się otwarta na dialog ze światem zewnętrznym, dostrzega rolę i znaczenie kultury w swoim indywidualnym życiu.

Zawarte powyżej rozważania wskazują na wartość i istotę narracji na mapie współczesnych paradygmatów. Wyodrębnienie się metody narracyjnej stało się ważnym „momentem historycznym”, w którym do głosu dochodzi człowiek ze swoimi rozterkami, wewnętrznymi napięciami, przełomowymi zdarzeniami, które pragnie opowiedzieć. Życie człowieka pełne niespodzianek, trudów, ale i radości dnia codziennego doczekało się ujawnienia. Narracje stworzyły zarówno badaczowi, jak i jednostce możliwość przyglądania się światu, relacji z tym światem. Sprzyjały subiektywnemu odczytaniu własnego postępowania w roli zwykłych członków społeczeństwa, osób zakorzenionych w kulturze, w swoich myślach, intencjach. W świecie, który jest zadany (badaczowi i narratorowi) do interpretacji. Człowiek stanął przed zadaniem zrozumienia siebie i otaczającego świata w takim stopniu, w jakim jest to możliwe. W takim ujęciu narrator „staje się osobą i pozostaje nią wyłącznie jako rozmówca (interlocutor)"29, chcący opowiedzieć historię swego życia. Opowieść narracyjna stała się okazją do wsłuchania się w wewnętrzny głos, chcący dobrowolnie ujawnić świat znaczących zdarzeń. Czyniąc siebie głównym bohaterem opowieści, narrator zaprasza do wędrówki po drodze indywidualnej historii życia. Mówi o „sobie samym jako innym"30, doświadcza upływu czasu, układa chronologicznie zdarzenia, próbuje zrozumieć sens swego istnienia. Rozpoczyna podróż w (nie)znane. Zmienia się w podglądacza uważnie śledzącego koleje swego losu ${ }^{31}$. Uważnie przygląda się swojej codzienności. Stara się zro-

29 J. Marzec, Dyskurs. Tekst. Narracja. Szkice o kulturze ponowoczesnej, Kraków 2002, s. 60.

30 P. Ricoeur, O sobie samym jako innym, Warszawa 2003.

31 A. Gerise, N. King, Tworzenie opowieści w edukacji i terapii, Warszawa 1999. 
zumieć sens i znaczenie zdarzeń, w które został uwikłany. Jego codzienność zapisuje kolejne karty biograficznego życia.

\section{Potrzeba snucia narracji jako opowieści w drodze}

Człowiek rodzi się z potrzebą opowiadania o tym wszystkim, co wokół niego się dzieje. Czyni to od pierwszych dni swojego życia, komunikując najbliższym stany radości, satysfakcji, zadowolenia, jak również gniewu, złości czy smutku. W taki sposób w procesie socjalizacji pierwotnej w rodzinie dziecko nawiązuje i podtrzymuje relacje interpersonalne z rodzicami. Tworzy się pomiędzy nimi więź, która zaprasza do codziennej, zwyczajnej komunikacji. Polega ona na opowiadaniu sobie nawzajem, co takiego w danej chwili się dzieje, co się odczuwa, co kieruje danym działaniem. Zapraszanie od najmłodszych lat do tworzenia spontanicznych opowieści daje wyraz swobodnemu odnoszeniu się do doświadczeń codziennego życia. Próbie zrozumienia, w czym jako podmioty uczestniczymy, co tworzymy swoim działaniem.

Życie jako narracja Jerome'a Brunera, Życie jako biografia Danuty Lalak, Historia życia Pierre'a Dominicé to tylko przykłady prac, w których poruszono istotę tworzenia opowieści w toku biograficznego życia. Wskazane prace podkreślają ważność potrzeby snucia opowieści opowieści w drodze temporalnego życia współczesnego człowieka. Czym jest zatem narracja $\mathrm{w}$ drodze, jak można ją rozumieć w kontekście życia człowieka uwikłanego w sieć relacji, związków z innymi ludźmi i samym sobą?

Narracja w drodze to próba wpisania indywidualnych doświadczeń w perspektywę czasu. Z punktu widzenia jednostki chodzi o jej prywatny świat zapamiętany z przeszłości, aktualne zainteresowanie teraźniejszością oraz oczekiwania skierowane ku antycypowanej przyszłości $^{32}$. Narracja w drodze odnosi się zatem do zdarzeń rozłożonych w czasie. Poprzez snutą opowieść narrator próbuje zrozumieć te ze zdarzeń, które w szczególny sposób zadecydowały o podjęciu ważnych,

32 Por. H. Worach-Kas, Metoda biograficzna jako badanie postaw wobec czasu, w: Metoda biograficzna $w$ socjologii, red. J. Włodarek, M. Ziółkowski, Warszawa-Poznań 1990. 
znaczących decyzji, wyznaczyły kierunek działań, zmotywowały do stawienia czoła problemom.

Kategoria pojęciowa czasu nabiera w tym miejscu szczególnego znaczenia. Człowiek zostaje niejako umiejscowiony w czasie ${ }^{33}$, podlega upływowi czasu, jest od niego zależny w wymiarze biologicznym, społecznym, fizycznym.

Czas określa wymiar ludzkiego istnienia, opisuje ciąg zdarzeń na linii biograficznego życia. Subiektywne odniesienie się do czasu ukazuje postawę jednostki wobec przeszłości, troskę o czas teraźniejszy czy ten niezwykle oczekiwany. Podział czasu na przeszłość, teraźniejszość i przyszłość daje zatem jednostce świadomość istnienia, umiejscowienia siebie i najbliższych osób w przestrzeni biograficznego biegu życia. Tym samym czas i jego upływ pozwalają człowiekowi doświadczać zmian, wewnętrznych przemian. Może temu sprzyjać wola zrozumienia własnych zachowań, podejmowanych decyzji, (nie)rozstrzygniętych problemów codziennego życia. Czas staje się niezwykle istotny w procesie doświadczania kluczowych zdarzeń, relacji z innymi czy samym sobą $\mathrm{w}$ toku indywidualnego rozwoju.

Próba rozczytania indywidualnych kart życia ujętych z perspektywy czasu kieruje człowieka ku opowieści narracyjnej, stwarzającej możliwości przyjrzenia się osobistemu doświadczeniu, zdobytej wiedzy o świecie, o samym sobie, zarówno z przeszłości, jak i z chwili obecnej. Czas określa percepcję aktualnego stanu, w tym oczekiwania i plany związane z nadchodzącą przyszłością ${ }^{34}$.

Dostrzeżenie istoty i znaczenia czasu $\mathrm{w}$ trakcie snucia opowieści narracyjnej wpisuje się w ludzką potrzebę uczynienia świata czytelnym, zrozumiałym, spójnym. Aby jednak było to możliwe, współczesny człowiek staje przed zadaniem porządkowania zdarzeń z własnej biografii w odcinki czasu. Czas może stać się sprzymierzeńcem w procesie nazywania, rozczytywania, poznawania dziejących się wokół jednostki zdarzeń. Może również na skutek zagęszczenia sytuacji dnia codziennego doprowadzić do bierności, zastoju, a nawet ucieczki od tego,

33 M. Kunicka, Temporalne orientacje teleologiczne nauczycieli, Kraków 2005.

34 Por. R. Nawrat, Orientacja temporalna. Przegląd technik pomiaru i wyników badań, „Przegląd Psychologiczny”, 1981 t. 1 nr 24, s. 99. 
co w danej chwili się dzieje. Spogląda zatem człowiek subiektywnie na swój świat. Próbuje go nazwać, na swój sposób wytłumaczyć, nadać mu (z)rozumienie. Narracja w drodze pokazuje doświadczanie upływu czasu, jego przemijanie, przeżywanie. Człowiek próbuje nadać sens i znaczenie zdarzeniom ważnym, znaczącym z perspektywy indywidualnej historii życia.

Odczuwanie potrzeby snucia opowieści w drodze kieruje człowieka ku gotowości odbycia podróży z sobą samym w przestrzeni narracyjnego czasu. To niewątpliwie potrzeba ponownego spotkania siebie w interakcji z innymi. Przyjrzenia się temu, co się zdarzyło, refleksyjnego postawienia pytania: co mogło się jeszcze wydarzyć. Wyrażenie wewnętrznej zgody na udział w tworzeniu narracji zanurza człowieka w czasowości jego ziemskiej egzystencji. Decyzja uporządkowania doświadczeń, znaczących biograficznie zdarzeń czy relacji z innymi w przestrzeni indywidualnej historii życia zaprasza do tworzenia autonarracji ujętej z perspektywy podmiotu zaangażowanego w odkrywanie swego subiektywnego świata.

Jak zauważa Piotr Oleś, autonarracja pozostaje pod wpływem ludzkiej motywacji. „Między autonarracją a motywacją zachodzi rodzaj sprzężenia zwrotnego. Motywacje znajdują wyraz i ukierunkowują autonarrację; jednocześnie, tworząc opowieść, osoba kieruje określoną motywacją: nadaje swej aktywności kierunek i wprowadza mechanizmy samokontroli" ${ }^{35}$. W autonarracji jednostka doświadcza potrzeby odkrywania siebie przez pryzmat analizy i interpretacji indywidualnej historii życia. Rozbudzenie wewnętrznej motywacji do porządkowania zdarzeń na drodze narracyjnej opowieści pozwala odwołać się do wspomnień i obrazów z przeszłości. Narrator staje się inteligentnym reżyserem ${ }^{36}$, który krok po kroku odkrywa w sobie możliwości porządkowania przeszłości i teraźniejszości w indywidualnej przestrzeni biograficznego życia. Autonarracja służy zatem współczesnemu człowiekowi do określania aktualnego miejsca na mapie jego świata. Jest podróżą,

35 P. Oleś, Autonarracyjna aktywność człowieka, w: Narracja. Teoria i praktyka, red. B. Janusz, K. Gdowska, B. Barbaro, Kraków 2008, s. 38.

36 D. Demetrio, Autobiografia. Terapeutyczny wymiar pisania o sobie, Kraków 2000. 
w którą udaje się człowiek. Nie możemy więc powiedzieć, że jest ona gotowa, zakończona, podsumowana ${ }^{37}$. Jako podmioty społeczne nieustanie interpretujemy, reinterpretujemy minione zdarzenia, nadajemy im sens i znaczenie w toku naszego rozwoju. Uczymy się spoglądać na minione zdarzenia z perspektywy czasu, z nutą krytycyzmu, nostalgią. Tak jak droga człowieka wiedzie po nieznanych szlakach, tak opowieść narracyjna może zaprowadzić do tych zakamarków przeżyć i doświadczeń, które przez długi czas były spowite „zmową milczenia”.

Ujawniająca się zatem potrzeba nazywania, porządkowania czy odkrywania indywidualnych doświadczeń może być wpisana w rozwój ludzkiej tożsamości. Stawianie fundamentalnych pytań: kim jestem? dokąd zmierzam? co jest sensem mojego życia? staje się sygnałem poszukiwań przez współczesnego człowieka swojego miejsca w świecie, wśród innych znaczących biograficznie osób. W takim ujęciu tożsamość okazuje się projektem refleksyjnym ${ }^{38}$. Daje ona jednostce poczucie bezpieczeństwa, podmiotowości, możliwości pokonania trudnych, determinujących sytuacji dnia codziennego. Katarzyna Rosner twierdzi, że rozumienie siebie, tego, w czym się uczestniczyło, musi wychodzić poza teraźniejszość. W tym ujęciu należy odwołać się do wszystkich wymiarów czasu „przeszłości, która opisuje to, czym jesteśmy, z perspektywy tego, czym byliśmy, i przyszłości - projektowanego kierunku"39. W taki oto sposób narracyjne rozumienie czasowości naszej egzystencji przekłada się na rozumienie rozwoju tożsamości.

Dzielenie się doświadczeniem wiąże się również z potrzebą uczestnictwa współczesnego człowieka w kulturze. Człowiek jako obywatel świata pragnie zrozumieć dziejące się wokół niego zdarzenia, sytuacje dnia codziennego, zjawiska globalne, działania podejmowane przez niego w skali mikro i makro. Podąża różnymi drogami współczesnego świata, dostrzega wielość i różnorodność problemów, w które sam jest uwikłany. Podejmuje odważny głos w dyskusji dotyczącej jego zaangażowania w rozwiązywanie problemów współczesnego świata. Pomoc-

37 B. Sobczak, Jesteśmy tym, co opowiadamy, w: Narracyjność języka i kultury. Literatura i media, red. D. Filar, D. Piekarczyk Lublin 2013.

38 K. Rosner, Narracja, tożsamość i czas, Kraków 2003.

39 Tamże, s. 35. 
na okazuje się niewątpliwie narracja w drodze, pozwalająca ujawniać z perspektywy doświadczającego podmiotu rozterki, wahania, wewnętrzną (nie)zgodę na problematyczność współczesnego świata. Jako aktywny podmiot, narrator utożsamia się z ludźmi o podobnych problemach, poglądach, daje wyraz swemu oburzeniu w spontanicznej, naturalnej narracji, w sytuacjach dnia codziennego, jako uczestnik kultury. Istota spotkania siebie, innych staje się wymowna. Na skutek wymiany zdań, stawiania nurtujących pytań, pobudzania się do refleksji narrator tworzy wokół siebie swoją indywidualną, specyficzną kulturę, w której jako podmiot się realizuje. Podejmowanie narracji w drodze pozwala zatem nie tylko poznawać kulturę, ale także czynić ją wartościową i znaczącą w obrębie codziennego życia.

Podjęte rozważania akcentują ludzką potrzebę snucia opowieści. W chaosie życia codziennego, natłoku spraw zatrzymanie się nad własną historią życia wydaje się konieczne. W odniesieniu do przeprowadzonych badań empirycznych ${ }^{40}$ podkreślamy ważność świadomego udziału narratorów w tworzeniu opowieści narracyjnych. Chęć dzielenia się z innymi ludźmi biograficznymi przeżyciami i doświadczeniami, próba porządkowania na linii czasu ważności dziejących się zdarzeń, próba zrozumienia ich konsekwencji dla dalszego biegu życia wyzwalają u narratorów wolę rekonstrukcji historii swego życia. Piotr Oleś ${ }^{41}$ wskazuje w tym kontekście na trzy grupy potrzeb: integracyjne, społeczne i tożsamościowe. Mówiąc o potrzebach integracyjnych, autor ma na myśli potrzebę zrozumienia znaczenia przeżytych zdarzeń, ich istotę, sens dla dalszego życia jednostki. Odczucie zaspokojenia potrzeb integracyjnych pozwala jednostce nadać życiu ciągłość poprzez odniesienie się do orientacji czasu: przeszłości, teraźniejszości i przyszłości w myśleniu indywidualnym. Potrzeby integracyjne ukierunkowują zatem działania jednostki na stworzenie spójności wokół dziejących się zdarzeń i sytuacji.

40 A. Krawczyk-Bocian, Doświadczanie zdarzeń krytycznych. Narracje biograficzne dorostych dzieci alkoholików, Bydgoszcz 2013; taż, Biograficzne doświadczanie (nie)pełnosprawności. W świetle teorii dezintegracji pozytywnej Kazimierza Dabrowskiego, Bydgoszcz 2016.

41 P. Oleś, Autonarracyjna aktywność człowieka, dz. cyt., s. 39-41. 
Kolejne potrzeby nazywa autor potrzebami społecznymi. Związane są one przede wszystkim z uczestnictwem jednostki w kulturze, w uniwersum symbolicznym. Kultura staje się łącznikiem pomiędzy jednostką a światem społecznym. W świecie sensów i znaczeń narrator odkrywa w sobie potrzebę dzielenia się z innymi swoimi doświadczeniami, szuka wokół siebie innych ludzi o podobnych przeżyciach, wchodzi z nimi w relacje i interakcje społeczne. Uniwersum symboliczne scala zarówno zdarzenia jednostkowe, jak i zbiorowe w całość. Zapewnia porządek w subiektywnym postrzeganiu siebie i swojego dotychczasowego życia. Należy dodać y, że ogromną rolę odgrywa w tym miejscu trzecia grupa potrzeb, jakimi są potrzeby tożsamościowe. Ich zaspokojenie pozwala narratorowi nadać sens indywidualnemu życiu. Pozwala odczuć, iż opowiedziana historia życia jest niepowtarzalna, wyjątkowa, unikatowa.

Narracja w drodze jest procesem. Jest zgodą współczesnego człowieka na poszukiwanie odpowiedzi na ważne, znaczące biograficznie pytania. Umiejętność podejmowania codziennej, zwyczajnej rozmowy prowadzi do refleksyjności, chwili zadumy, zatrzymania się choć na moment w chaosie ludzkiego życia. Tworząc narrację, człowiek pochyla się nad własną historią życia. Pragnie ją poznać, zrozumieć, odczytać na nowo. Przygląda się z boku samemu sobie, ocenia się krytycznie, odnosi się do świata wartości, wiedzy, wzorców kultury, dziedzictwa przekazywanego z pokolenia na pokolenie. Jest ciekaw miejsca, w którym z różnych powodów się znalazł. Narracja w drodze pozwala zrozumieć siebie i swoje aktualne miejsce w świecie sensów i znaczeń.

\section{Świat sensów i znaczeń współtworzący symboliczną interakcję}

Proces odkrywania przeżyć i doświadczeń kieruje narratora ku interakcji, jaką nawiązuje ze sobą i innymi ludźmi w przestrzeni swego najbliższego świata. Prowadząc wewnętrzny dialog, narrator pochyla się nad indywidualną historią swego życia. Podejmuje wysiłek językowego opisania, wyrażenia emocji, myśli i refleksji, które towarzyszyły mu w procesie biograficznego doświadczania. Zanurzony w czasowości swego ziemskiego egzystowania narrator odkrywa krok po kroku 
sensy i znaczenia przeżytych zdarzeń w biografii indywidualnej. Wprowadza siebie w symboliczną interakcję, próbując wyczytać (rozczytać) świat swoich doznań i przeżyć. W polu interakcyjnym czyni siebie podmiotem, sprawcą dziejących się wokół zdarzeń. Uważnie przygląda się sobie, wraca do zdarzeń i sytuacji, które stały się jego udziałem. W tym ujęciu rozpoczyna rozmowę z samym sobą, pragnie rozmówić się ze swoją przyszłością, snuje opowieść o tym wszystkim, co z jego punktu widzenia stało się ważne i znaczące dla zrozumienia tego, kim dzisiaj jest, co osiągnął, co udało mu się wypracować w czasie ziemskiej wędrówki. Otrzymany w języku opowieści obraz świata współczesnego człowieka ukazuje repertuar strategii radzenia sobie z trudnymi, determinującymi sytuacjami, zdarzeniami. Pokazuje zdolność człowieka do zmian, konstruktywnego wypracowania reguł i zasad pomocnych w okiełznaniu trudów codziennego życia. Język narracyjnej opowieści staje się „sam w sobie narracją o świecie, narracją tych, którzy ten język tworzyli i tworzą"42.

Podążanie za wewnętrznym głosem uczynienia świata zrozumiałym daje wyraz ludzkiej pracy nad ustawicznym (re)definiowaniem siebie w procesie biograficznych przemian. Stąd też, jak twierdzi Olga Tokarczuk: „nasze życie jest nie tylko sumą zdarzeń, lecz skomplikowanym splotem sensów, które tym zdarzeniom przypisujemy. Owe sensy tworzą cudowną tkaninę opowieści, pojęć, idei i można ją uznać za jeden z żywiołów - jak powietrze, ziemia, ogień i woda - które fizycznie determinują nasze istnienie i nas kształtują"43. Opowieść w drodze umożliwia zatem nie tylko spoglądanie na to, co było. Pozwala określić działania, podejmowane zadania, wyznacza kierunek zmian. Jest nastawiona na realizację celów, odkrywanie tego, co nowe, nieznane czy obce. Narrator w symbolicznej interakcji ze sobą odczuwa potrzebę udziału zarówno w indywidualnym, jak i społecznym procesie tworzenia przestrzeni życia. Jako podmiot aktywnie zaangażowany w rozczytanie owego świata przeżyć i doświadczeń uzewnętrznia swoje emocje

42 D. Kępa-Figura, Narracja na płaszczyźnie werbalnej. Na przykładzie przekazu medialnego, w: Narracyjność języka i kultury. Literatura i media, red. D. Filar, D. Piekarczyk, Lublin 2013, s. 169.

43 O. Tokarczuk, Czuły narrator, Kraków 2020, s. 23-24. 
i pragnienia. Ukazuje indywidualny i społeczny świat pełen niespodzianek, doznań, upadków. Czyni to przed samym sobą z zamiarem komunikowania potrzeb i pragnień wpisanych w jego ludzką potrzebę nadawania życiu sensu i znaczenia.

W przestrzeni symbolicznej interakcji wychodzi również poza siebie. Symbolicznie zaprasza do spotkania wszystkich tych, którzy są ciekawi jego życia, historii, wyjątkowości przeżytych zdarzeń. To dzielenie się $\mathrm{z}$ innymi swym życiem ukazuje świadomą, refleksyjną jednostkę biorącą udział w procesie kreowania i tworzenia przestrzeni biograficznego życia. Inni ludzie wydają się ważni, biograficznie znaczący. To oni przyczynili się do porządkowania codziennych doświadczeń narratora na linii czasu. To oni odegrali istotną rolę w zwyczajnym, codziennym procesie komunikacji. Być może właśnie oni stali się iskrą zachęcającą do tworzenia opowieści w drodze.

W symbolicznej interakcji narrator pragnie rozczytać, co Inni do niego mówią, co przekazują, w jaki sposób układają z nim relacje interpersonalne. Narracja w drodze pozwala zatrzymać się nie tylko przy pytaniach trudnych, lecz także tych, które do tej pory się nie pojawiły, nie zostały zwerbalizowane. Narracja w drodze pozwala zatem ,zapuścić się" w zakamarki tych ludzkich spraw, które do tej pory spychane były na margines jako nieważne, nieistotne, powierzchowne. Narracji w drodze towarzyszy przekonanie, że „każdy jest kimś wyjątkowym i że ma wyjątkowe, sobie właściwe możliwości”'44.

Wydobywanie sensów i znaczeń staje się procesem poznawczym. $\mathrm{W}$ takim ujęciu jednostka odczuwa nieustanną potrzebę stawiania pytań i poszukiwania na nie odpowiedzi. Czyni to z zamiarem uchwycenia w całej rozciągłości przeżytych doświadczeń, możliwości (z)rozumienia, co tak właściwie się wydarzyło. Własna aktywność narratora staje się źródłem poznania, dostarcza informacji zwrotnych o samym sobie, daje poczucie istnienia, jest fundamentem budowania i rozwoju tożsamości. Przeżycie spotkania zmienia jego relacje z samym sobą i innymi w przestrzeni społecznego życia.

44 A. Majewska-Kafarowska, Narracje biograficzne a poczucie tożsamości kobiet, Katowice 2010, s. 30. 
Z jednej strony spotkanie ze sobą może sprzyjać (z)rozumieniu miejsca, w którym obecnie narrator się znajduje. Może sprzyjać rozbudzeniu otwartości, gotowości do pracy nad własną biografią, sprzyjać budowaniu nowych, ciekawych związków z innymi. W takim ujęciu narrator będzie postrzegany jako refleksyjny, krytyczny podmiot, który wzywa samego siebie do podjęcia wysiłku uczynienia życia sensownym, wartościowym, opartym na miłości i poszanowaniu siebie i Innych. Z drugiej strony spotkanie ze sobą na drodze narracyjnej może sprzyjać ucieczce, wycofaniu, poddaniu się temu, co jest tu i teraz. W takiej sytuacji wewnętrzny konflikt nie zostaje rozwiązany, a człowiek czuje się zagubiony i pozostawiony samemu sobie. Stąd też należy wiedzieć, że w wymiarze poznawczym metoda narracyjna dostarcza jednostce wiedzy o jej potencjale, możliwościach, ale i ograniczeniach, słabościach. Praca nad biograficznymi przeżyciami wyznacza kierunek wewnętrznych i zewnętrznych zmian, przemian, nad którymi narrator może się refleksyjnie pochylić.

Odkrycie biograficznych sensów i znaczeń staje się zadaniem dla współczesnego człowieka. Bycie w zgodzie ze sobą wzmacnia sferę psychicznego życia, niesie ulgę i wyciszenie. Nie każdy jest jednak na takie wyzwanie gotów. Stąd też istotna i niezwykle ważna w życiu człowieka wydaje się przywołana wcześniej w rozważaniach kategoria pojęciowa przebaczenia ${ }^{45}$. Możemy na nią spojrzeć jako na lekarstwo, które skutecznie odnosi się do minionych zdarzeń, daje upust emocjom, pozwala zrozumieć konsekwencje poczynań własnych i innych ludzi wokół. Człowiek oswaja się ze sobą, swoimi potrzebami, pragnieniami, które tworzą poczucie jego istnienia. W taki sposób doświadczanie siebie w trakcie narracyjnej drogi sprzyja konstrukcji swojego Ja, rozumienia siebie i świata, rozumieniu siebie wobec świata ${ }^{46}$. Człowiek staje się twórczym podmiotem $\mathrm{w}$ procesie samookreślenia indywidualnego planu życia, do realizacji którego świadomie dąży.

45 P. Ricoeur, Pamięć, historia, zapominanie, dz. cyt.

46 A. Skibiński, Narracje i autonarracje tożsamości: kodowanie siebie-jako-innego, w: Narracje w życiu. O grupie i jednostce, red. J. Wasilewski, Warszawa 2016, s. 167. 


\section{Narracja świadka zdarzeń i sytuacji dnia codziennego}

Dalszym rozważaniom będzie towarzyszyła kategoria pojęciowa narracja świadka.

Termin narracja świadka zapożyczamy od Johna Beverleya ${ }^{47}$. W tekście Narracja świadka, podrzędność i autorytet narracyjny autor zauważa, że narracja świadka jest współcześnie formą powszechnie używaną, różnorodną, stąd może odnosić się do takich określeń, jak: wyznanie, świadectwo sądowe, pamiętnik, historia życia i inne ${ }^{48}$.

W kontekście podjętych rozważań spróbujemy spojrzeć na narrację świadka jako szczególnego rodzaju opowieść narracyjną wyartykułowaną w pierwszej osobie liczby pojedynczej. Zwrot Ja będzie stanowił punkt wyjścia opisu zdarzeń, sytuacji dnia codziennego, rozumienia ich, nadawania im sensu i znaczenia z perspektywy czasu.

W prowadzonym wcześniej wywodzie staraliśmy się wykazać, że podjęcie narracji w drodze staje się dla człowieka okazją do rozpoznania siebie, swoich potrzeb, pragnień, budowania obrazu siebie w plątaninie pytań, obszarów nierozpoznanych, dotąd nieujawnionych. W związku z powyższym można powiedzieć, że narrator staje się świadkiem zdarzeń, w które został uwikłany bądź w których sam uczynił się głównym bohaterem. Narracja świadka przybiera zatem postać spotkania z samym sobą. Dzieje się to z perspektywy tej osoby, która jest najbardziej zorientowana $\mathrm{w}$ tym, co się wydarzyło. Relacjonowanie minionych zdarzeń, związków ze sobą i z innymi ludźmi wprowadza narracyjnego świadka zdarzeń w stan zatrzymania. W narracyjnym zatrzymaniu dominuje cisza, skupienie na twarzy, zaduma. Człowiek otrzymuje czytelny sygnał, że powoli zanurza się w refleksji i w odtwarzaniu przeżyć i doświadczeń.

Narracja świadka kieruje uwagę na postawione pytania: kim dzisiaj jestem? kim byłem? kim chcę być w antycypowanej przyszłości? Pytanie: kim? sugeruje już na wstępie, że świadek zdarzenia pragnie spojrzeć na siebie i swoje życie z dystansu. Próba odpowiedzi na jakże

47 J. Beverley, Narracja świadka, podrzędność i autorytet narracyjny, w: Metody badań jakościowych, red. N.K. Denzin, Y.S. Lincoln, Warszawa 2009.

48 Tamże, s. 761. 
trudne pytanie wiedzie go ku zdarzeniom z przeszłości, które pragnie po imieniu nazwać, nadać im chronologiczny porządek, doprowadzić do momentu teraźniejszego, momentu, w którym obecnie się znajduje. W narracji świadka może się również pojawić zaimek kto wyartykułowany w pytaniach: kto do mnie mówi? co do mnie mówi? co chce przekazać? Paul Ricoeur ${ }^{49}$ odpowiedziałby, że człowiek, który stawia tego typu pytania, to ten, który potrafi „określić samego siebie jako wypowiadającego swoją wypowiedź”. Świadek staje zatem przed zadaniem określenia samego siebie, zaakcentowania ważności czy doniosłości swojej roli jako uczestnika w procesie rozczytania historii życia.

Świadek zdarzenia staje się więc aktywnym, twórczym podmiotem zaangażowanym w odkrywanie dziejących się wokół zdarzeń. Czyni to po to, aby mógł powiedzieć, że jest „autorem, źródłem i sprawcą wpływu tak na zewnętrzną, jak i wewnętrzną rzeczywistość" ${ }^{50}$. Podejmuje się zatem pełnienia funkcji informacyjnej, opisowej, sprawozdawczej oraz interpretacyjnej wobec zdarzeń, których doświadczył ${ }^{51}$. W pierwszej kolejności informuje swoje otoczenie społeczne o ważnych biograficznie zdarzeniach, momentach znaczących, których doświadczył. Próbuje zaznaczyć ich ważność, dokonuje rozpoznania, nazwania po imieniu sytuacji, które z jego perspektywy przyczyniły się do zmian zarówno $\mathrm{w}$ nim samym, jak i w najbliższym otoczeniu społecznym. Aby mógł jednak to uczynić, poszukuje wokół siebie innych ludzi, którzy tak jak on są świadkami podobnych zdarzeń, bądź osób, które zechcą wsłuchać się w jego indywidualną historię życia. Znajdując osoby chętne czy ciekawe jego historii życia, szczegółowo opisuje zdarzenia, relacjonuje główne wątki, opisuje ludzi, z którymi wiązały go (bądź nadal wiążą) relacje miłości, przyjaźni czy wrogości i nienawiści.

Przedstawia sprawozdanie $\mathrm{z}$ tego, co miało miejsce, co się wydarzyło. Z perspektywy czasu ponownie pochyla się nad istotą danego zdarzenia, próbuje nadać mu sens i znaczenie. Dokonuje wartościowania spotkań z innymi ludźmi w przestrzeni swego biograficznego ży-

49 P. Ricoeur, Filozofia osoby, Kraków 1992, s. 37.

50 M. Kuleta, Człowiek jako kreator zmian w swoim życiu, w: Człowiek wobec zmiany. Rozważania psychologiczne, red. D. Kubacka-Jasiecka, Kraków 2002, s. 21.

51 A. Krawczyk-Bocian, Homo narrator, Bydgoszcz 2021. 
cia, krytycznie ocenia ich oddziaływanie na niego i swój stosunek do nich. Z perspektywy czasu podejmuje się pełnienia roli interpretacyjnej. Określa swoje miejsce na mapie zdarzeń, odnosi się do ludzi wokół niego, relacji z nimi. Wyraża wątpliwości, szydzi, oskarża, broni. Przywołuje emocje, które towarzyszyły mu w trakcie zdarzenia, tuż po nim, jak i w chwili obecnej. Dygresja towarzyszy mu w całym procesie powrotu do zdarzeń z przeszłości. Daje mu to poczucie bycia podmiotem własnych działań, sprawcą własnego losu' ${ }^{52}$.

Narracja świadka zdarzeń dostarcza wiedzy o uczestnictwie współczesnego człowieka w rozpoznaniu i nazwaniu po imieniu problematyczności świata. Zobrazowany, opisany własnym językiem świat przeżyć i doświadczeń umożliwia ogląd dziejących się wokół nas zdarzeń, relacji ze znaczącymi innymi, które przyczyniły się do uczynienia świata czytelnym, zrozumiałym. Na podstawie relacji świadka zdarzenia możemy sformułować pytania: $w$ jaki sposób sami zachowalibyśmy się w podobnej sytuacji? jaką podjęlibyśmy decyzję? do kogo udalibyśmy się po pomoc i wsparcie w trudach codziennego życia? Utożsamiając się ze świadkiem zdarzenia, przyjmujemy jego punkt widzenia na temat zdarzeń wokół nas, próbujemy odnieść się do nich w kontekście swojej wiedzy i własnych biograficznych doświadczeń. Narracja świadka wpisuje się w codzienne, ziemskie bytowanie w świecie sensów i znaczeń. Doświadczenie twarzy drugiego człowieka ${ }^{53}$ pozwala zatem nie tylko odsłonić jego wizerunek, podejrzeć jego życie. Spotykając na swojej drodze innych ludzi, uruchamiamy proces pobudzania się do refleksji, zadumy, zatrzymania się wokół indywidualnej historii życia, porządkowania własnych doświadczeń, precyzowania myśli poprzez ich werbalizację.

W narracji świadka zdarzeń odkrywamy samych siebie. To podążanie za głosem wspomnień prowadzi ku możliwości przyglądania się temu, co w chwili obecnej z nami się dzieje. Obserwowaniu tego, co nas szczególnie niepokoi, męczy, drażni. W rezultacie otrzymujemy informację zwrotną na temat tego, co warto by zmienić bądź czemu warto wyznaczyć inny kierunek. Narracja świadka zdarzeń przynosi zatem

52 M. Nowak-Dziemianowicz, Podmiot $w$ narracjach. Narracja, autobiografia, tożsamość, „Forum Oświatowe”, 2008 nr specjalny, s. 128.

53 J. Tischner, Filozofia dramatu, Paris 1990. 
wiedzę wszystkim osobom współtworzącym przestrzeń najbliższego świata. Sprzyja nie tylko oglądowi świata innych ludzi, ale przede wszystkim swego własnego, indywidualnego, domagającego się chwilowego postoju, zatrzymania, otwarcia się na to, co dzieje się w chwili obecnej, „tu i teraz”.

Z powyższych rozważań wynika, że każda „rzeczywistość, w której żyją ludzie, może być odczytana jako nieme lub głośne wołanie człowieka o pomoc w rozumieniu tego, co w nim i dokoła niego się dzieje"54. W narracyjnej drodze człowiek ma szansę spotkać się z najważniejszą osobą: samym sobą.

\section{(Z)rozumienie istoty spotkania (siebie i Innych) w narracyjnej drodze}

Kiedy mówimy o spotkaniu, zazwyczaj odwołujemy się do relacji pomiędzy ludźmi. Mamy wtedy na myśli istotę bycia w przestrzeni dwóch osób: Ja i Ty. Pomiędzy dwoma wskazanymi podmiotami dochodzi do szczególnej interakcji, opartej na zrozumieniu, empatii, woli wsłuchania się w opowieść życia. Z taką sytuacją spotykamy się w codziennej ludzkiej interakcji, w zwyczajnym ludzkim opowiadaniu sobie nawzajem o tym, co nam się przydarza. Osobliwe spotkanie z drugim człowiekiem odbywa się również podczas przebiegu badań biograficzno-narracyjnych. Wtedy to badacz staje się aktywnym słuchaczem podążającym za historią życia narratora. To właśnie narrator krok po kroku wprowadza badacza w zakamarki swego świata, pozwala dotrzeć do tych z nich, które z perspektywy procesu badawczego są istotne, kluczowe dla zrozumienia miejsca, w którym obecnie się znajduje.

Proces badawczy angażuje oba podmioty tego osobliwego spotkania. Spróbujmy się temu przyjrzeć. Badacz, chcąc opisać, wyjaśnić, zinterpretować wybrany przez siebie obszar z życia człowieka, poszukuje osób zainteresowanych tym przedsięwzięciem. Nie jest to zadanie proste. Dotarcie do osób chcących opowiedzieć obcej, nieznanej osobie historię

54 L. Górska, Podmiot i podmiotowość $w$ wychowaniu. Studium w perspektywie poznawczej pedagogiki integralnej, Szczecin 2008, s. 15. 
swego życia przysparza wielu kłopotów. Jednym z nich jest niewątpliwie brak ufności współczesnego człowieka i jego obawa przed odkrywaniem czy ujawnianiem tych zdarzeń z życia, które wydają mu się szczególnie ważne, znaczące, intymne, osobiste. Innym powodem może być brak umiejętności werbalizowania własnych przeżyć i doświadczeń, czy też brak umiejętności radzenia sobie z emocjami, panowania nad nimi w trakcie snucia opowieści o swoim życiu. Jakiekolwiek byłyby powody niechęci do snucia opowieści, odmowę należy uszanować. Współczesny człowiek staje się odpowiedzialny za słowo, które wyraża istotę jego życia, sens tego wszystkiego, co z jego perspektywy wydaje się ważne i znaczące dla biograficznego momentu, w którym się znalazł.

$\mathrm{W}$ procesie badawczym pojawiają się jednak osoby wyrażające wolę snucia opowieści o swoim życiu. Czynią to z powodu chęci pozostawienia części swojej historii potomnym bądź tym ludziom, którzy mogą uczyć się z ich biografii. W takim ujęciu mamy do czynienia ze szczególnym rodzajem spotkania narracyjnego. Pomiędzy badaczem a narratorem tworzy się więź oparta na zaufaniu, zaangażowaniu, otwartości i akceptacji drugiego człowieka. Owa akceptacja związana jest przede wszystkim z przełamywaniem przez badacza stereotypów potocznego myślenia o drugim człowieku, jego życiu, podejmowanych działaniach czy decyzjach. Spotkanie narracyjne staje się otwartą komunikacją, w której jest „świat do odkrycia, pełen nieznanych skarbów”55. Spotkanie narracyjne może stać się punktem zwrotnym, przełomowym w życiu człowieka, może zapoczątkować proces nazwany odkryciem prawdy o sobie ${ }^{56}$. To proces, pod wpływem którego narrator rozpoczyna rozmyślanie o sobie i swoim dotychczasowym życiu z perspektywy minionego czasu. Spogląda na kwestie związane ze swoim wychowaniem w rodzinie, zachodzącymi w nim relacjami, uczeniem się biograficznym, związkami przyjaźni i miłości. Bacznie przygląda się temu, co zrobił, jakie podjął decyzje, krytycznie ocenia to, do czego one doprowadziły.

55 J.C. Kaufmann, Wywiad rozumiejacy, Warszawa 2010, s. 79.

56 A. Krawczyk-Bocian, Narracja w pedagogice, dz. cyt., Bydgoszcz 2019. 
Spotkanie ze sobą „,wytrąca człowieka z jego dotychczasowych sposobów myślenia"57. Pojawiająca się refleksja prowadzi ku próbie ponownego nazwania po imieniu: w czym człowiek uczestniczył, czego doznał, w jaki sposób może odnieść się do zdarzeń z perspektywy minionego czasu. Spotkanie ze sobą powoduje, że narrator wyraża głębokie przekonanie o potrzebie nadania życiu sensu. W takim ujęciu spotkanie siebie w jakże refleksyjnej narracyjnej drodze odgrywa rolę terapeutyczną ${ }^{58}$, strukturyzującą doświadczenie ${ }^{59}$, komunikującą innym znaczenie biograficznych doświadczeń ${ }^{60}$.

Mówiąc o terapeutycznej roli opowieści narracyjnej, mamy na myśli możliwość oceny zdarzeń z przeszłości przez pryzmat teraźniejszości. Ogląd swojego życia z perspektywy teraźniejszej daje możliwość powrotu do zdarzeń z przeszłości, przyglądania się im z dystansu, niekiedy w zawieszeniu czy chwilowym bezruchu. Jak zaznacza Duccio Demetrio $^{61}$ : „ten niezwykle urodzajny grunt stwarza nieograniczone możliwości wyrażania odmiennych sposobów czucia i eksponowania nowych metod analizy i obserwacji świata wewnętrznego i zewnętrznego". Perspektywa czasu staje się sprzymierzeńcem w odkryciu zdarzeń z przeszłości. Zwroty typu „mogłem się wygadać”, „dobrze zrzucić to z siebie" stają się wyrazem aktywnego zaangażowania narratorów w proces rozpoznawania siebie i obszarów swego życia.

Próba analizy i interpretacji życia stanowi dla człowieka źródło wiedzy o sobie. Strukturyzowanie biograficznych doświadczeń ujawnia się w potrzebie nadania życiu sensu. Odzwierciedlanie obrazu własnej osoby w perspektywie czasu pozwala wytworzyć dystans do zdarzeń minionych, samego siebie i ludzi wokół. W opowieści narracyjnej przeżyte

57 A. Ryk, Pedagogika dramatu. Poszukiwania antropologiczno-metodologiczne, Kraków 2008, s. 36.

58 U. Tokarska, Narracja autobiograficzna $w$ terapii i promocji zdrowia, w: Narracja jako sposób rozumienia świata, red. J. Trzebiński, Gdańsk 2002.

59 A. Grzegorek, Narracja jako forma strukturyzująca doświadczenie, w: Doświadczenie indywidualne, red. K. Krzyżewski, Kraków 2003.

60 D. Urbaniak-Zając, Wywiad narracyjny na tle innych technik wywiadu, „Edukacja", 1999 nr 4.

61 D. Demetrio, Autobiografia. Terapeutyczny wymiar pisania o sobie, dz. cyt., S. 14. 
zdarzenie staje się wyjątkowe, niepowtarzalne. Nie zdarza się wielokrotnie, tylko ten jeden raz. W związku z powyższym zdarzenia skierowane są $\mathrm{w}$ jedną stronę na osi czasu ${ }^{62}$. Strukturyzowanie doświadczeń stawia zatem narratora $\mathrm{w}$ pierwszoplanowej roli bohatera (aktora), przed którym stoi ważne zadanie: reprezentacja zdarzeń, biograficznych przeżyć i doświadczeń w kontekście indywidualnego udziału w tworzeniu historii życia.

Ciekawość i aktywność badawcza kieruje narratora ku próbie dotarcia do zakamarków swego dotychczasowego życia. Wymowne staje się uchwycenie tego, co ulotne czy do tej pory niedoścignione. Aktywność, jaką podejmuje narrator, jest narzędziem służącym powolnemu zapisywaniu kart własnej biografii. Uruchomiony proces introspekcji sprzyja tym samym nabywaniu przez człowieka samowiedzy, odkrywaniu indywidualnych stanów psychicznych, integrujących go z samym sobą w sferze emocjonalnej, intelektualnej czy duchowej ${ }^{63}$. Podczas spotkania ze sobą narrator uzewnętrznia myśli, spostrzeżenia, ujawnia motywy swego działania, podejmowane przez siebie decyzje. Strukturyzuje doświadczenia, aby móc wędrówkę po swoim życiu doprowadzić do momentu, w którym obecnie się znajduje. Porządkowanie doświadczeń na linii czasu staje się wyzwaniem warunkującym akceptację swego dotychczasowego życia, próbą zrozumienia prawdy o sobie z perspektywy podmiotu kształtującego tożsamość osobową i społeczną.

Doświadczenie istoty spotkania decydująco zmienia obraz człowieka, jego relacje ze sobą, z innymi ludźmi w przestrzeni biograficznego świata. Ujawniająca się potrzeba komunikowania innym ludziom przełomowych zdarzeń daje świadectwo woli ponownego zanurzenia się w to, co kiedyś miało miejsce. Dziać się to może na skutek niedostatecznego przepracowania zdarzeń z przeszłości bądź ujęcia ich z perspektywy nieważnych czy nieistotnych. Narrator zaprasza siebie do głębszego przeżywania doświadczeń, które w niedalekiej przeszłości (na skutek pośpiechu czy nieuwagi) zostały pominięte, zapomnia-

62 J. Trzebiński, Narracyjne formy wiedzy potocznej, Poznań 1992, s. 84.

63 M. Barański, Model introspekcji personalistycznej zawarty $w$ antropologii Karola Wojtyły a poznanie prawa naturalnego, „Forum Prawnicze”, 2016 nr 2(34), s. 47. 
ne ${ }^{64}$. Komunikuje zatem ludziom wokół istotę przeżytych zdarzeń, zaznacza ich wpływ na podjęte decyzje, poszukuje wokół siebie Innych o podobnych doświadczeniach i przeżyciach w przestrzeni najbliższego mu świata. Następuje widoczny aspekt przemiany w relacji jednostki z samym sobą ${ }^{65}$. Narrator doświadcza swojej inności, odmienności, postrzega siebie jako kreatora zmian (przemian). Uczy się bycia ze sobą w przestrzeni codziennego życia, które nazwał ponownie w kontekście przeżytych biograficznie zdarzeń. Zaprasza Innych do wsłuchania się w historię jego życia.

To ponowne spotkanie siebie w biograficznych doświadczeniach pozwala mu tworzyć narrację dla siebie - o sobie. Wprowadza ona ład i porządek w znaczące dla jednostki obszary biograficznego życia. Daje podstawę poszukiwania sensu i znaczeń dziejących się wokół zdarzeń, sprzyja ukazywaniu swojej różnorodności czy inności.

Zrozumienie istoty spotkania siebie w drodze staje się „temporalną formą znaczenia"66. Zatrzymanie się w czasie teraźniejszym sprzyja twórczej pracy nad rozpoznaniem swego Ja, nazwaniu po imieniu relacji z samym sobą, stanów emocjonalnych, w których narrator obecnie się znajduje. Przełamywanie stereotypów potocznego myślenia o samym sobie pozwala sięgać do przeszłości, refleksyjnie spoglądać na oczekiwaną przyszłość, budować teraźniejszość opartą na akceptacji siebie takim, jakim w danej chwili się jest. Wytworzenie zgody na (z)rozumienie świata przeżyć i doświadczeń pozwala przezwyciężyć trudne, determinujące zdarzenia, umożliwia odnowienie zapomnianych kontaktów interpersonalnych, odnalezienie miejsca wśród innych biograficznie znaczących osób.

Tworzenie indywidualnego planu rozwoju ukierunkowuje działania nastawione na wysiłek i pracę wokół nadania życiu sensu. Próba odpowiedzi na fundamentalne pytanie: co jest sensem mojego życia? kieruje

64 Por. D. Demetrio, Autobiografia. Terapeutyczny wymiar pisania o sobie, dz. cyt.

65 F. Schütze, G. Riemann, Trajektoria jako podstawowa koncepcja teoretyczna $w$ analizach cierpienia i bezładnych procesów społecznych, „Kultura i Społeczeństwo", 1992 nr 2, s. 94.

66 D. Śleszyński, Wędrówka doświadczenia: podejście fenomenologiczne i egzystencjalne, Białystok 1998, s. 37. 
ku woli odczytania swoich intencji, poczucia swego istnienia, zadomowienia w świecie dostarczającym biograficznych wzlotów i upadków. Spotkanie ze sobą sprzyja tworzeniu spójnej konstrukcji swojego Ja, rekonstrukcji minionych zdarzeń, budowaniu antycypowanej przyszłości w drodze akceptacji siebie i swojego dotychczasowego życia. Człowiek staje się wewnętrznie wolnym podmiotem, tworzy wokół siebie „pole wolności”"67, w którym podejmuje ważne życiowe decyzje, odpowiedzialne wybory. Otwartość i zaangażowanie poznawcze czynią go jednostką doświadczającą przemian w czasie. W takim ujęciu narracja tworzy rzeczywistość, a rzeczywistość tworzy narrację. Dzięki napływającym informacjom człowiek jest w stanie zrozumieć najbliższy mu świat. Funkcjonuje w tym świecie zgodnie $\mathrm{z}$ wiedzą o nim, regułach w nim rządzących. Przeżywa swoje życie, opierając się na doświadczeniach, które wpisują się w jego codzienną biografię.

Spotkanie ze sobą pozwala zrozumieć bieg życia. Stanowi źródło wiedzy w procesie konstruowana i tworzenia sądów, uczuć, przekonań. Pozwala uczestniczyć w rodzinnym, społecznym, zawodowym świecie znaczeń. Tworzy historię opartą na interakcji zarówno ze sobą, jak i z innymi w świecie wspólnych biograficznych doświadczeń. Taki sposób rozumienia daje możliwość krytycznego odniesienia się do zdarzeń z przeszłości, zdarzeń minionych. Pozwala na dokonanie zmian w swoich postawach, zachowaniach, w systemie wartości68. Spotkanie uświadamia narratorowi złożoność i różnorodność jego interakcji w drodze ziemskiego bytowania. Daje wyraz ważności przekazu, który tworzy i przekazuje zarówno sobie, jak i potomnym. Narrator uświadamia sobie rolę, jaką odgrywa w przekazywaniu Innym ważnych, znaczących doświadczeń. Podejmując rozmowę ze sobą, bierze pod uwagę fakt, że „warunkiem jego zaistnienia jest gotowość do mówienia praw-

67 K. Obuchowski, Człowiek intencjonalny, Warszawa 1993.

68 U. Dębska, Autonarracja - droga odkrywania i konstruowania prawdy o sobie, w: Narracja. Koncepcje i badania psychologiczne, red. E. Dryll, A. Cierpka, Warszawa 2004, s. 214. 
dy i przyjmowania prawdy drugiej osoby"69. W takiej sytuacji narrator będzie gotów przyznać, iż „narracja naśladuje życie, życie naśladuje narrację"70. Narrator staje się temporalnym uczestnikiem codziennego życia. Czas (przeżyty czas) ujawnia w formie narracji.

\section{Potoczne pojmowanie znaczenia opowieści narracyjnych $w$ drodze}

Narracje w potocznym znaczeniu znajdują swoje miejsce w literaturze przedmiotu (zob. prace Trzebińskiego, Bauman ${ }^{71}$, Conle, Marca wymienione $\mathrm{w}$ bibliografii). Są one związane $\mathrm{z}$ opowiadaniem historii swego życia innym osobom napotkanym w codzienności. W tym przypadku mamy do czynienia z uruchomieniem procesu komunikacji pomiędzy osobą chcącą ujawnić własnym głosem swój świat doznań i przeżyć a ludźmi z najbliższej grupy społecznej, jak i ogółu społeczeństwa, chcącymi danej historii wysłuchać. Narracje w potocznym znaczeniu odnoszą się zatem do świata codziennego jednostki, jej osobistych doświadczeń oraz znaczeń, jakie nadaje temu, co przeżyła.

W kontekście poruszanej problematyki nadrzędną kategorią pojęciową staje się wiedza potoczna. Mowa o tym obszarze wiedzy, który zdobywa człowiek w toku swobodnego, naturalnego rozwoju, w drodze codziennych kontaktów ze światem zewnętrznym, innymi ludźmi, w toku różnorakich interakcji społecznych. Jak zauważa Teresa Hejnicka-Bezwińska ${ }^{72}$, wokół refleksji i badań nad potocznością pojawiły się takie kategorie pojęciowe, jak: życie codzienne, świat przeżywany, świat życia, świat oczywisty, jak również myślenie potoczne czy zdro-

69 E. Dryll, Analiza tekstu narracji autobiograficznej z wykorzystaniem metod lingwistyki formalnej, w: Narracja. Teoria i praktyka, red. B. Janusz, K. Gdowska, B. Barbaro, Kraków 2008, s. 117.

70 J. Marzec, Dyskurs. Tekst. Narracja. Szkice o kulturze ponowoczesnej, dz. cyt., s. 61.

${ }^{71}$ Teresa Bauman podejmuje się rozważań na temat wiedzy lokalnej. Wskazuje na jej szczegółowość związaną z tworzeniem jednostkowej wizji siebie i świata oraz porównywanie pozwalające dowiedzieć się czegoś więcej o innych przypadkach.

${ }^{72}$ T. Hejnicka-Bezwińska, Pedagogika ogólna, Warszawa 2008, s. 58. 
wy rozsądek. Wiedza potoczna wpisana zatem będzie w obszar świata życia jednostki, która indywidualnie doświadcza, przeżywa czy doznaje w kontekście własnej tożsamości, rozwoju osobowego i społecznego spotkań z innymi ludzi w przestrzeni swego codziennego życia. Dominować w niej będą informacje epizodyczne, wyrażane za pomocą języ$\mathrm{ka}_{\text {potocznego }}{ }^{73}$. Będzie to zatem wiedza osobista, indywidualna, wynikająca z codziennych doświadczeń jednostki, mająca dla niej sens i znaczenie.

Podstawą rozwoju wiedzy potocznej staje się dla człowieka rodzina. To właśnie najbliższa rodzina w procesie socjalizacji pierwotnej wyposaża dziecko w system wartości, znaczeń, symboli, którymi sama się kieruje. Wzrastanie u boku rodziny, wyznawanie jej zasad, wpisywanie się w jej reguły codziennego bytowania wyznacza kierunek dalszego biegu życia jednostkowego i społecznego. Wyposażenie dziecka od najmłodszych lat w wiedzę potoczną daje mu możliwości rozczytania znaków i kodów współczesnego świata czy też podejmowania wszelkich interpretacji codziennego życia. W taki sposób jednostka uzyskuje możliwości odniesienia się do doświadczeń własnych, zdobywanych $\mathrm{w}$ toku indywidualnych interakcji, jak i tych przekazywanych ustnie bądź pisemnie przez starsze pokolenia ( $\mathrm{w}$ tym pokolenia osób starszych czy biograficznie „znaczących innych”).

Wiedza potoczna o świecie ma swe źródło w doświadczaniu obecności innych osób. Jest ona zatem wynikiem relacji z ludźmi, z którymi jednostka wchodzi w codzienne, zwyczajne kontakty. Jest obszarem, w którym przeżywane są stany emocjonalne, te przysparzające zawirowań, kłopotów, ale i radości związanych z poczuciem rozwoju osobowego czy satysfakcji z osiągniętych zamierzeń. Stąd też, jak zauważa Alfred Schütz ${ }^{74}$ : „człowiek znajduje się w każdym momencie swego codziennego życia w biograficznie zdeterminowanej sytuacji, w zdefiniowanym przez siebie fizycznym i społeczno-kulturowym środowisku. To

73 Zob. Pedagogika. Leksykon, red. B. Milerski, B. Śliwerski, Warszawa 2000, s. 163.

74 A. Schütz, Potoczna i naukowa interpretacja ludzkiego działania, w: Kryzys i schizma. Antyscjentystyczne tendencje $w$ socjologii współczesnej, t. 1, red. E. Mokrzycki, Warszawa 1984, s. 145. 
właśnie w nim ma swoje miejsce, nie tylko to, które jest określone przez fizyczną przestrzeń i zewnętrzny czas czy status i rolę w społecznym systemie, ale także zajmuje pewne moralne i ideologiczne stanowisko. Powiedzieć, że definicja sytuacji jest biograficznie zdeterminowana, to przyznać, że ma ona swoją historię, którą stanowi nawarstwienie wszystkich uprzednich doświadczeń zorganizowanych w stale posiadany przez niego zasób wiedzy podręcznej, zasób unikalny, dany jemu i tylko jemu". Przedmiotem swoich rozważań czyni zatem Schütz nie tylko to, co w życiu człowieka jasne, czytelne, odkryte. Wręcz przeciwnie. Autor pochyla się nad tym, co w życiu codziennym człowieka jest ukryte, zamaskowane, co domaga się ujawnienia w procesie komunikowania się z innymi czy z samym sobą.

Ów świat życia codziennego żąda od człowieka jego opisania, wyjaśnienia i zinterpretowania. Jednostka podejmuje się tego zadania z przekonaniem, że uczyni go zrozumiałym, czytelnym, jasnym. Odwołuje się zatem do swojej indywidualnej wiedzy potocznej, która pozwala odpowiedzieć na nurtujące pytania, a zarazem otwiera płaszczyznę do problematyzowania, inicjowania dyskursu ze sobą i innymi w przestrzeni świata społecznego.

Najważniejszym systemem znaków pozwalającym zdefiniować sytuację (w tym problemową), w której znajduje się jednostka, staje się język. To właśnie dzięki niemu jest ona w stanie nie tylko mówić sama do siebie, w myśli. Język otwiera przestrzeń do dyskursu, wymiany zdań, poglądów, opinii. Cały świat staje przed człowiekiem otworem. W języku ludzkie wnętrze ,znajduje swój pełny, wyczerpujący i obiektywnie zrozumiały wyraz"75. W takim ujęciu język, w tym język potoczny, staje się dla człowieka instrumentem tworzącym przestrzeń do podjęcia dialogu z samym sobą w codziennych, zwyczajnych spotkaniach, jak i z Innymi, których do rozmowy zaprasza.

Ważność języka potocznego znajduje swoje odzwierciedlenie w podejmowanych przez człowieka narracyjnych opowieściach. Opowiadając własnym głosem, własnym językiem historię swego życia, człowiek chce być zrozumiany przede wszystkim przez siebie samego. To wyjąt-

75 W. Dilthey, Pisma estetyczne, Warszawa 1982, s. 293. 
kowa moc i zdolność języka do wyrażania, artykułowania stanów emocjonalnych, w których obecnie człowiek się znajduje. Służy temu niewątpliwie intonacja głosu, jego chwilowe zawieszenie czy powrót do rozważań ze zmienioną już barwą głosu. To bardzo ważne cechy języka, którym posługuje się w codzienności człowiek. Potwierdzają to choćby słowa Petera L. Bergera i Thomasa Luckmanna ${ }^{76}$, którzy twierdzą, że „zanim ludzie poznają samych siebie, muszą o sobie mówić”. To właśnie proste, zwyczajne mówienie wprowadza człowieka w różne obszary jego społecznego funkcjonowania. Pozwala mu przyglądać się samemu sobie niejako z boku, z dystansu, z nutą krytycyzmu. Mówienie o sobie umożliwia opisywanie zdarzeń, sytuacji z dnia codziennego, pozwala łączyć je na linii czasu, pobudza tym samym do działania. Mówienie o sobie stawia w konsekwencji jednostkę przed zadaniem nadania sensu i znaczenia podjętym zadaniom i wyzwaniom codziennego życia.

Opowieść współczesnego człowieka wyrażona w języku potocznym pozwala mu zrozumieć miejsce, jakie zajmuje w biograficznej przestrzeni. Stawianie fundamentalnych pytań, próba poszukiwania na nie odpowiedzi, mówienie o sobie w sposób otwarty, krytyczny i refleksyjny sprzyjają tym samym kształtowaniu tożsamości. Wyrażanie potrzeb i pragnień w narracyjnym języku ${ }^{77}$, języku codziennej opowieści, pobudza człowieka do pokonywania ograniczeń codziennego życia, wyznacza pole do nowych wyzwań czy kreślenia swojej antycypowanej przyszłości. Z perspektywy pedagogiki mamy zatem do czynienia z bogactwem wiedzy, danych i informacji o życiu i zmaganiach człowieka, który jako aktywny, twórczy podmiot stara się sprostać wymaganiom współczesnego świata. Dzięki podejmowanym opowieściom narrator ma możliwość odczytania i zrozumienia swego wewnętrznego i zewnętrznego świata. Obserwator tego świata ma z kolei możliwość przyjrzenia się temu światu „tu i teraz” oraz doświadczania życia przez pryzmat przeżyć innych osób.

76 P.L. Berger, T. Luckmann, Społeczne tworzenie rzeczywistości, dz. cyt., s. 74.

77 Takiego określenia używa Carola Conle w tekście Praktyka i teoria badań narracyjnych $w$ edukacji, w: Habermas, teoria krytyczna i edukacja, red. M. Murphy, T. Fleming, Wrocław 2012. 
Wyłoniona w toku snucia opowieści potoczna wiedza o sobie jest przede wszystkim wiedzą człowieka o celach, do których dąży, oraz warunkach i środkach prowadzących do ich realizacji ${ }^{78}$. Zdaniem Jerzego Trzebińskiego ${ }^{79}$ umysłową bazą do tworzenia takich opowieści są schematy narracyjne.

W schemacie narracyjnym wyłania się bohater opisujący historię swego życia i doświadczający jej. Odgrywa on pierwszoplanową rolę w schemacie narracyjnym, gdyż właśnie wokół niego dzieją się zdarzenia stanowiące podstawę snucia opowieści. Narrator ponownie powraca zatem do świata swoich indywidualnych przeżyć i doświadczeń, przygląda się swemu dotychczasowemu życiu, poszukuje prawdy o sobie, konfrontuje własną wizję siebie z doświadczeniami innych osób w tym zakresie, co w konsekwencji prowadzi go do zrozumienia miejsca, punktu biograficznego, w którym obecnie się znajduje ${ }^{80}$. Wiedza, jaką uzyskuje człowiek podejmujący się trudu narracyjnego opowiadania, daje mu poczucie istnienia $\mathrm{w}$ biograficznym czasie. Pozwala mu odnieść własną osobę do doznań sensorycznych, emocjonalnych, doznań towarzyszących podejmowaniu decyzji czy doznań związanych z tzw. impulsem do działania ${ }^{81}$.

Uruchomiony wewnętrzny proces motywacyjny do uzyskania wiedzy o sobie kieruje narratora ku stawianiu fundamentalnych pytań: kim jestem? dokąd zmierzam? co chcę w życiu osiągnąć? jakich muszę podjąć się zadań, wyzwań, aby osiągnąć zamierzony cel? Sam proces formułowania pytań staje się już dla narratora skarbnicą wiedzy o samym sobie jako podmiocie zdolnym do rekonstrukcji swego dotychczasowego życia. Zdefiniowanie celu, wyznaczenie kierunku działań prowadzi następnie jednostkę ku przestrzeni wypełnionej zadaniami czy wyzwaniami czekającymi na realizację. Pojawiające się po drodze komplikacje, sytuacje trudne, determinujące mogą stać się dla człowieka sygnałem nadchodzących zagrożeń, którym będzie musiał stawić czoła. Poszukiwanie w sobie środków zaradczych, rozglądanie się wo-

78 J. Trzebiński, Narracyjne formy wiedzy potocznej, dz. cyt., s. 81-93.

79 J. Trzebiński, Narracyjne konstruowanie rzeczywistości, dz. cyt.

80 Por. J. Trzebiński, Narracyjne formy wiedzy potocznej, dz. cyt.

81 Tamże, s. 83. 
kół za pomocą i wsparciem mogą okazać się szansą na przezwyciężenie trudności i w konsekwencji realizację zamierzonych celów. Za Jerzym Trzebińskim ${ }^{82}$ można zatem stwierdzić, że: „W ramach schematu narracyjnego określona sfera świata jawi się człowiekowi jako przestrzeń, w której dzieją się szczególnego rodzaju historie, a mianowicie historie polegające na tym, że typowe dla sfery postaci, mające określone intencje, napotykają na specyficzne, powtarzające się problemy, a otoczenie i ich własne cechy - tworząc warunki radzenia sobie z nimi - przesądzają o szansach ich przezwyciężenia".

rezultat:

schemat narracyjny

wiedza potoczna forma:

opowiadanie

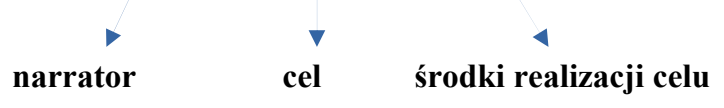

Opracowanie własne za: J. Trzebiński, Narracyjne konstruowanie rzeczywistości, w: Narracja jako sposób rozumienia świata, red. J. Trzebiński, Gdańsk 2002.

Decydując się na formę narracyjnego opowiadania, narrator zaprasza niejako sam siebie do podążania za głosem wewnętrznych rozterek, wątpliwości, pytań. Mówiąc o sobie w pierwszej osobie liczby pojedynczej, pochyla się nad własną historią życia, zapytuje sam siebie: „co ( $\mathrm{Ja})$ czuję?”, „,o (Ja) myślę?”, „co (Ja) odczuwam?”, co ( Ja) chcę zmienić?”. W taki sposób wyrażanie świata wewnętrznych doznań wzbogaca życie człowieka o nową wiedzę o samym sobie jako podmiocie biograficznych przeżyć.

Próba odczytania siebie i swego życia jest niewątpliwie procesem twórczym, czasochłonnym, ukierunkowanym na odczytanie poszczególnych obszarów dotychczasowego życia, nastawionym na przezwyciężanie trudności i niedogodności współczesnego świata. W codzien-

82 J. Trzebiński, Narracyjne konstruowanie rzeczywistości, dz. cyt., s. 23. 
nych kontaktach z samym sobą to właśnie język staje się wymownym znakiem poruszającym się po subiektywnym świecie przeżyć i doświadczeń. Język staje się towarzyszem intencji i działań człowieka. W kontekście podejmowanej tematyki potoczny język opowieści może uczynić subiektywność życia człowieka „bardziej rzeczywistą” nie tylko dla partnera w rozmowie, ale także dla samego zainteresowanego owym spotkaniem $^{83}$.

Stąd też opowiadanie staje się formą najbliższą człowiekowi już od najmłodszych lat. Daje ono początek kompetencji narracyjnej, czyli swobodnemu wypowiadaniu się, opowiadaniu o tym, co się człowiekowi (przydarza) przydarzyło w indywidualnym biegu życia. Wyrażanie świata poprzez opowiadanie, opisywanie go na podstawie posiadanej wiedzy potocznej pozwala przyglądać się światu innych ludzi. Pozwala uczyć się z biograficznych przeżyć ludzi żyjących obok nas, doświadczających każdego dnia trudów codziennego życia.

Wiedza potoczna staje się nieodłącznym elementem ludzkiego bytowania. Obszarem, w którym człowiek uzyskuje dostęp do zakamarków swego świata, przeżywanego indywidualnie bądź przy udziale innych osób.

\section{Zakończenie}

Podjęte rozważania wokół kategorii pojęciowej narracji (w drodze) podkreślają jej ważność i znaczenie w obrębie kultury współczesnego człowieka. Dostrzeżenie jej walorów w procesie odkrywania, nazywania i interpretowania obszarów z życia człowieka doprowadziło, zdaniem Jacques'a Derridy ${ }^{84}$, do „rozpalenia sensu”. Ów sens związany był z ludzką potrzebą odkrywania zakamarków codziennego bytowania wśród innych ludzi, jak i z samym sobą. Poszukiwanie odpowiedzi na nurtujące pytania stało się nadrzędne. Współczesny człowiek chce wiedzieć, co się z nim i wokół niego dzieje, w czym uczestniczy,

83 P.L. Berger, T. Luckmann, Społeczne tworzenie rzeczywistości, dz. cyt., s. 74.

84 Za: J. Marzec, Dyskurs. Tekst. Narracja. Szkice o kulturze ponowoczesnej, dz. cyt., s. 55. 
z czym sobie (nie) radzi, co go frustruje, zasmuca, z czego czerpie radość i satysfakcję. W taki sposób narracja stała się uniwersalnym pojęciem wkraczającym powoli w obszar wielu nauk. Narracja jako forma opowiadania o sobie z perspektywy czasu umożliwiła podjęcie dyskursu pomiędzy człowiekiem a światem jego codziennego życia.

Zabranie głosu w dyskusji na temat indywidualnych doświadczeń i przeżyć z biograficznego życia ukazało człowieka z perspektywy twórczego podmiotu, przyjmującego rolę aktora zdarzeń, w które został uwikłany. Komunikowanie przed samym sobą, jak i innymi, biograficznie znaczącymi, indywidualnych przeżyć stało się możliwe dzięki zdolności do (re)konstrukcji świata codziennych doznań, wewnętrznej gotowości do porządkowania zdarzeń na linii czasu. Sprzymierzeńcem w owym procesie stał się język zdolny do wymiany zdań, poglądów, opinii na temat tego, co współczesnego człowieka dręczy, co sprawia mu kłopot, co wymaga zdefiniowania, opisania czy wyjaśnienia.

Opowiadanie historii życia zogniskowanej wokół obszaru rodzinnego, zawodowego, społecznego pozwala zarówno narratorowi, jak i słuchaczom (czytelnikom) zrozumieć miejsce człowieka w przestrzeni codziennego życia. W takim ujęciu akt narracji przybliża człowieka do samego siebie. Zbliża do innych ludzi, którzy identyfikują się z jego życiem, wyzwaniami, rozterkami. Akt narracji pozwala narratorowi rozpoznać to, co niejasne, wątpliwe, niewypowiedziane. Stąd też „opowiadanie o sobie to odpowiedzialne przedsięwzięcie, które stanowić winno

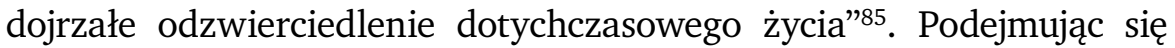
wyzwania ujawnienia indywidualnej historii życia, narrator staje się odpowiedzialny za słowo, którym opisuje świat wewnętrznych przeżyć.

Podążając za doświadczeniami innych osób, jako obywatele społecznego świata mamy możliwość zrozumienia, co z nami samymi się dzieje, w co jesteśmy uwikłani, z czym musimy sobie radzić, jakie podejmujemy decyzje, jakich dokonujemy wyborów, jakie są ich konsekwencje.

85 D. Demetrio, Autobiografia. Terapeutyczny wymiar pisania o sobie, dz. cyt., s. 19. 
Z punktu widzenia obserwatorów świata kultury opowieść narracyjna staje się społecznym źródłem wiedzy o każdym z nas, osadzonym $\mathrm{w}$ indywidualnym świecie przeżyć i doświadczeń ${ }^{86}$.

\section{Bibliografia}

Adamiec, Marek. Doświadczenie przemiany jako kategoria psychologiczna. Katowice: Wydawnictwo Uniwersytetu Śląskiego, 1988.

Barański, Michał. „Model introspekcji personalistycznej zawarty w antropologii Karola Wojtyły a poznanie prawa naturalnego". Forum Prawnicze t. 34 nr 2 (2016): 45-58.

Bauman, Teresa. „Poznawczy status danych jakościowych”. W: Metodologiczne problemy tworzenia wiedzy $w$ pedagogice. Oblicza akademickiej praktyki, red. Jacek Piekarski, Danuta Urbaniak-Zając, Krzysztof Szmidt, 91-105. Kraków: Oficyna Wydawnicza IMPULS, 2011.

Berger, Peter L. Luckmann, Thomas. Społeczne tworzenie rzeczywistości. Traktat z socjologii wiedzy, tłum. Józef Niżnik. Warszawa: Państwowy Instytut Wydawniczy, 1983.

Beverley, John. „Narracja świadka, podrzędność i autorytet narracyjny”, tłum. Maria Świątkiewicz Mośny. W: Metody badań jakościowych, t. 1, red. Norman K. Denzin, Yvonna S. Lincoln, 761-774. Warszawa: Wydawnictwo Naukowe PWN, 2009.

Bruner, Jerome. „Życie jako narracja”. Kwartalnik Pedagogiczny nr 4 (1990): 3-17.

Burzyńska, Anna. „Idee narracyjności w humanistyce”. W: Narracja. Teoria i praktyka, red. Bernadetta Janusz, Katarzyna Głodowska, Bogdan de Barbaro, 21-36. Kraków: Wydawnictwo Uniwersytetu Jagiellońskiego, 2008.

Chase, Susan E. „Wywiad narracyjny. Wielość perspektyw, podejść, głosów", tłum. Filip Schmidt. W: Metody badań jakościowych, t. 2, red. Norman K. Denzin, Yvonna S. Lincoln, 3-55. Warszawa: Wydawnictwo Naukowe PWN, 2009.

86 A. Schütz, Potoczna i naukowa interpretacja ludzkiego działania, dz. cyt., s. 150. 
Chądzyńska, Małgorzata. „Modalność w tekście a ustosunkowanie do świata. Wybrane aspekty metody badania autonarracji". W: Narracja. Teoria i praktyka, red. Bernadetta Janusz, Katarzyna Głodowska, Bogdan de Barbaro, 171-188. Kraków: Wydawnictwo Uniwersytetu Jagiellońskiego, 2008.

Conle, Carola. „Praktyka i teoria badań narracyjnych w edukacji”, tłum. Elżbieta Kalinowska. W: Habermas, teoria krytyczna i edukacja, red. Mark Murphy, Ted Fleming, 179-196. Wrocław: Wydawnictwo Naukowe Dolnośląskiej Szkoły Wyższej, 2012.

Cuprjak, Magdalena. 2016. „Paradygmaty w perspektywie zmian społecznych. Zarys problemu". Rocznik Andragogiczny t. 23 (2016): 251-265. DOI: http://dx.doi.org/10.12775/RA.2016.013.

Czerniawska, Olga. „Podróż w pamięci starszych”. Edukacja Dorosłych nr 1 (2003): 39-46.

Demetrio, Duccio. Autobiografia. Terapeutyczny wymiar pisania o sobie, tłum. A. Skolimowska. Kraków: Oficyna Wydawnicza IMPULS, 2000.

Denzin, Norman K. „Reinterpretacja metody biograficznej w socjologii: znaczenie a metoda w analizie biograficznej", tłum. N. Nowakowska. W: Metoda biograficzna w socjologii, red. Jan Włodarek, Marek Ziółkowski, 55-69. Warszawa-Poznań: Państwowe Wydawnictwo Naukowe, 1990.

Denzin, Norman K. „Wprowadzenie. Dziedzina i praktyka badań jakościowych", tłum. Krzysztof Podemski. W: Metody badań jakościowych, t. 1, red. Norman K. Denzin, Yvonna S. Lincoln, 19-62. Warszawa: Wydawnictwo Naukowe PWN, 2009.

Dębska, Urszula. „Autonarracja - droga odkrywania i konstruowania prawdy o sobie". W: Narracja. Koncepcje i badania psychologiczne, red. Elżbieta Dryll, Anna Cierpka, 209-216. Warszawa: Wydawnictwo Instytutu Psychologii PAN, 2004.

Dijk, Teun A. van. „Działanie, opis działania a narracja”, tłum. Maria Bożena Fedewicz. Pamiętnik Literacki. Czasopismo Kwartalne Poświęcone Historii i Krytyce Literatury Polskiej t. 76 nr 1 (1985): 145-166.

Dilthey, Wilhelm. Pisma estetyczne, tłum. Krystyna Krzemieniowa. Warszawa: Państwowe Wydawnictwo Naukowe, 1982.

Dilthey, Wilhelm. „Rozumienie i życie”, tłum. Grzegorz Sowiński. W: Wokót rozumienia. Studia i szkice z hermeneutyki, red. Grzegorz Sowiński, 41-94. Kraków: Wydawnictwo Naukowe Papieskiej Akademii Teologicznej, 1993.

Dominicé, Pierre. „Historia życia (life history)”. W: Narracja - krytyka-zmiana. Praktyki badawcze we współczesnej pedagogice, red. Mirosława Nowak- 
-Dziemianowicz, Ewa Kurantowicz, 155-159. Wrocław: Wydawnictwo Naukowe Dolnośląskiej Szkoły Wyższej, 2007.

Dryll, Elżbieta. Analiza tekstu narracji autobiograficznej z wykorzystaniem metod lingwistyki formalnej. W: Narracja. Teoria i praktyka, red. Bernadetta Janusz, Katarzyna Głodowska, Bogdan de Barbaro, 116-129. Kraków: Wydawnictwo Uniwersytetu Jagiellońskiego, 2008.

Dryll, Elżbieta. „Homo narrans - wprowadzenie”. W: Narracja. Koncepcje i badania psychologiczne, red. Elżbieta Dryll, Anna Cierpka, 7-20. Warszawa: Wydawnictwo Instytutu Psychologii PAN, 2004.

Gałdowa, Anna. Powszechność i wyjątek. Rozwój osobowości człowieka dorosłego. Kraków: Wydawnictwo Księgarni Akademickiej, 1995.

Gerise, Alida. King, Nancy. Tworzenie opowieści w edukacji i terapii, tłum. Katarzyna Rustecka. Warszawa: Wydawnictwo Cyklady, 1999.

Górska, Lucyna. Podmiot i podmiotowość $w$ wychowaniu. Studium $w$ perspektywie poznawczej pedagogiki integralnej. Szczecin: Wydawnictwo Naukowe Uniwersytetu Szczecińskiego, 2008.

Grzegorek, Anna. „Narracja jako forma strukturyzująca doświadczenie”. W: Doświadczenie indywidualne. Szczególny rodzaj poznania i wyróżniona postać pamięci, red. Krzysztof Krzyżewski, 209-225. Kraków: Wydawnictwo Uniwersytetu Jagiellońskiego, 2003.

Hejnicka-Bezwińska, Teresa. Pedagogika ogólna. Warszawa: Wydawnictwa Akademickie i Profesjonalne, 2008.

Hejnicka-Bezwińska, Teresa. Praktyka edukacyjna $w$ warunkach zmiany kulturowej (w poszukiwaniu logiki zmian). Warszawa: Wydawnictwo Naukowe PWN, 2015.

Kaufmann, Jean-Claude. Wywiad rozumiejacy, tłum. Alina Kapciak. Warszawa: Oficyna Naukowa, 2010.

Kępa-Figura, Danuta. „Narracja na płaszczyźnie werbalnej. Na przykładzie przekazu Medialnego". W: Narracyjność języka i kultury. Literatura i media, red. Dorota Filar, Dorota Piekarczyk, 167-184. Lublin: Wydawnictwo Uniwersytetu Marii Curie-Skłodowskiej, 2013.

Krawczyk-Bocian, Amelia. Biograficzne doświadczanie (nie)petnosprawności. $W$ świetle teorii dezintegracji pozytywnej Kazimierza Dąbrowskiego. Bydgoszcz: Wydawnictwo Uniwersytetu Kazimierza Wielkiego, 2016.

Krawczyk-Bocian, Amelia. Doświadczanie zdarzeń krytycznych. Narracje biograficzne dorostych dzieci alkoholików. Bydgoszcz: Wydawnictwo Uniwersytetu Kazimierza Wielkiego, 2013. 
Krawczyk-Bocian, Amelia. Homo narrator. Bydgoszcz: Wydawnictwo Uniwersytetu Kazimierza Wielkiego, 2021.

Krawczyk-Bocian, Amelia. Narracja w pedagogice. Teoria. Metodologia. Praktyka badawcza. Bydgoszcz: Wydawnictwo Uniwersytetu Kazimierza Wielkiego, 2019.

Kruszelnicki, Wojciech. Zwrot refleksyjny w antropologii kulturowej. Wrocław: Wydawnictwo Naukowe Dolnośląskiej Szkoły Wyższej, 2012.

Kuleta, Małgorzata. „Człowiek jako kreator zmian w swoim życiu”. W: Człowiek wobec zmiany. Rozważania psychologiczne, red. Dorota Kubacka-Jasiecka, 21-37. Wydawnictwo Uniwersytetu Jagiellońskiego, Kraków 2002.

Kunicka, Małgorzata. Temporalne orientacje teleologiczne nauczycieli. Kraków: Oficyna Wydawnicza Impuls, 2005.

Lalak, Danuta. Życie jako biografia. Podejście biograficzne w perspektywie pedagogicznej. Warszawa: Wydawnictwo Akademickie ŻAK, 2010.

Majewska-Kafarowska, Agnieszka. Narracje biograficzne a poczucie tożsamości kobiet. Katowice: Wydawnictwo Uniwersytetu Śląskiego, 2010.

Marzec, Jarek. Dyskurs. Tekst. Narracja. Szkice o kulturze ponowoczesnej. Kraków: Oficyna Wydawnicza Impuls, 2002.

Marzec, Jarek. „«Narratologia» ponowoczesna: uniwersalizm metafory narracji w kulturze współczesnej”. Teraźniejszość - Człowiek - Edukacja nr 2 (10) (2000): 91-103.

Mazurek, Emilia. „Narracyjne uczenie się człowieka dorosłego. Założenia teoretyczne". Nauki o Wychowaniu. Studia Interdyscyplinarne nr 1(4) (2017): 106-117. DOI: https://doi.org/10.18778/2450-4491.04.07.

Nawrat, Ryszard. „Orientacja temporalna. Przegląd technik pomiaru i wyników badań”. Przegląd Psychologiczny t. 1 nr 24 (1981): 97-124.

Nowak-Dziemianowicz, Mirosława. „Podmiot w narracjach. Narracja, Autobiografia, Tożsamość". Forum Oświatowe numer specjalny (2008): 181-194.

Obuchowski, Kazimierz. Człowiek intencjonalny. Warszawa: Wydawnictwo Naukowe PWN, 1993.

Oleś, Piotr. „Autonarracyjna aktywność człowieka”. W: Narracja. Teoria i praktyka, red. Bernadetta Janusz, Katarzyna Głodowska, Bogdan de Barbaro, 37-52. Kraków: Wydawnictwo Uniwersytetu Jagiellońskiego, 2008.

Pedagogika. Leksykon, red. Bogusław Milerski, Bogusław Śliwerski. Warszawa: Wydawnictwo Naukowe PWN, 2000.

Ricoeur, Paul. Filozofia osoby, tłum. Małgorzata Frankiewicz. Kraków: Wydawnictwo Naukowe Papieskiej Akademii Teologicznej, 1992. 
Ricoeur, Paul. O sobie samym jako innym, tłum. Bogdan Chełstowski. Warszawa: Wydawnictwo Naukowe PWN, 2003.

Ricoeur, Paul. Pamięć, historia, zapomnienie, tłum. Janusz Margalski. Kraków: Wydawnictwo Universitas, 1995.

Rosner, Katarzyna. „Narracja jako struktura rozumienia”. Teksty Drugie nr 3 (1999): 7-15.

Rosner, Katarzyna. Narracja, tożsamość i czas. Kraków: Wydawnictwo Universitas, 2003.

Ryk, Andrzej. Pedagogika dramatu. Poszukiwania antropologiczno-metodologiczne. Kraków: Wydawnictwo Naukowe Akademii Pedagogicznej, 2008.

Schütz, Alfred. „Potoczna i naukowa interpretacja ludzkiego działania”, tłum. Dorota Lachowska. W: Kryzys i schizma. Antyscjentystyczne tendencje w socjologii wspótczesnej, t. 1, red. Edmund Mokrzycki, 137-192. Warszawa: Państwowy Instytut Wydawniczy, 1984.

Schütze, Fritz. Riemann, Gerhard. „Trajektoria jako podstawowa koncepcja teoretyczna w analizach cierpienia i bezładnych procesów społecznych". Kultura i Społeczeństwo t. 36 nr 2 (1992): 89-109.

Skibiński, Adam. „Narracje i autonarracje tożsamości: kodowanie siebie-jako-innego". W: Narracje w życiu. O grupie i o jednostce, red. Jacek Wasilewski, 161-170. Warszawa: Oficyna Wydawnicza ASPRA-JR, 2016.

Sobczak, Barbara. „Jesteśmy tym, co opowiadamy”. W: Narracyjność języka i kultury. Literatura i media, red. Danuta Filar, Danuta Piekarczyk, 101-116. Lublin: Wydawnictwo Uniwersytetu Marii Curie-Skłodowskiej, 2013.

Straś-Romanowska, Maria. „Psychologia wobec małych i wielkich narracji”. W: Psychologia matych i wielkich narracji, red. Maria Straś-Romanowska, Bogna Bartosz, Magdalena Żurko, 21-40. Warszawa: „Eneteia” Wydawnictwo Psychologii i Kultury, 2010.

Śleszyński, Dariusz. Wędrówka doświadczenia: podejście fenomenologiczne i egzystencjalne. Białystok: Wydawnictwo Uniwersyteckie Trans Humana, 1998.

Tischner, Józef. Filozofia dramatu. Paris: Editions du dialogue, 1990.

Tokarczuk, Olga. Czuły narrator. Kraków: Wydawnictwo Literackie, 2020.

Tokarska, Urszula. „Narracja autobiograficzna w terapii i promocji zdrowia”. W: Narracja jako sposób rozumienia świata, red. Jerzy Trzebiński, 232261. Gdańsk: Gdańskie Wydawnictwo Psychologiczne, 2002.

Trzebiński, Jerzy. Narracyjne formy wiedzy potocznej. Poznań: Wydawnictwo „Nakom”, 1992. 
Trzebiński, Jerzy. „Narracyjne konstruowanie rzeczywistości”. W: Narracja jako sposób rozumienia świata, red. Jerzy Trzebiński, 17-42. Gdańsk: Gdańskie Wydawnictwo Psychologiczne, 2002.

Trzebiński, Jerzy. „Problematyka narracji we współczesnej psychologii”. W: Narracja. Teoria i praktyka, red. Bernadetta Janusz, Katarzyna Głodowska, Bogdan de Barbaro, 9-17. Kraków: Wydawnictwo Uniwersytetu Jagiellońskiego, 2008.

Urbaniak-Zając, Danuta. „Wywiad narracyjny na tle innych technik wywiadu". Edukacja nr 4 (1999): 29-40.

Worach-Kardas, Halina. „Metoda biograficzna jako badanie postaw wobec czasu". W: Metoda biograficzna w socjologii, red. Jan Włodarek, Marek Ziółkowski, 113-123. Warszawa-Poznań: Państwowe Wydawnictwo Naukowe, 1990. 